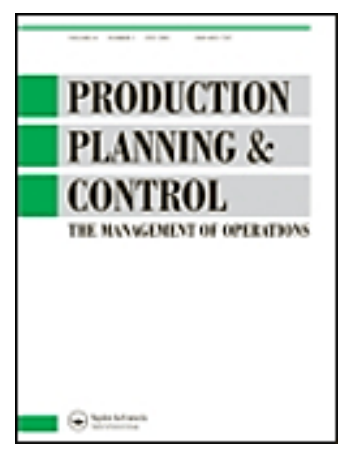

\title{
Systematic Review and Discussion of Production Control Systems that emerged between 1999 and 2018
}

\begin{tabular}{|r|l|}
\hline Journal: & Production Planning \& Control \\
\hline Manuscript ID & TPPC-2019-0255.R3 \\
\hline Manuscript Type: & Research paper for Regular Issue \\
\hline Author: & $\mathrm{n} / \mathrm{a}$ \\
\hline Complete List of Authors: & $\begin{array}{l}\text { Bagni, Gustavo; Federal University of São Carlos, Industrial Engineering } \\
\text { Godinho Filho, Moacir; Federal University of São Carlos, Industrial } \\
\text { Engineering } \\
\text { Thürer, Matthias ; Jinan University } \\
\text { Stevenson, Mark; Lancaster University, Dept. of Management Science }\end{array}$ \\
\hline Keywords: & $\begin{array}{l}\text { card-based system, production system, production control system, } \\
\text { production control, COBACABANA }\end{array}$ \\
\hline &
\end{tabular}

\section{SCHOLARONE ${ }^{m}$ Manuscripts}




\title{
Systematic Review and Discussion of Production Control Systems that emerged between 1999 and 2018
}

\author{
Gustavo Bagnia*, Moacir Godinho Filho ${ }^{\mathrm{a}}$, Matthias Thürer ${ }^{\mathrm{b}}$ and Mark \\ Stevenson ${ }^{\mathrm{c}}$ \\ ${ }^{a}$ Industrial Engineering, Federal University of São Carlos, São Carlos, Brazil; ${ }^{\text {SSchool }}$ \\ of Intelligent Systems Science and Engineering, Jinan University, Guangzhou, China; \\ ${ }^{c}$ Management Science, Lancaster University, Lancaster, United Kingdom; \\ *gustavobagni@uol.com.br
}




\title{
Systematic Review and Discussion of Production Control Systems that emerged between 1999 and 2018
}

\author{
There exists a large literature on well-known Production Control Systems (PCS) \\ such as Kanban, Constant Work-In-Process (CONWIP), Material Requirements \\ Planning (MRP) and Paired Cell Overlapping Loops of Cards with Authorization \\ (POLCA). However, there are also many new systems that have emerged in the \\ last 20 years. These systems are less well known, and no systematic review \\ exists. Through a systematic literature review, 13 PCS's were identified, such as \\ COBACABANA, REDUTEX, BK- CONWIP and B-CONWIP. For each system, \\ we describe its characteristics, how they work and in what productive \\ environments it proves useful. A cross-comparison of the 13 systems was then \\ conducted using seven variables: primary control variable (WIP or throughput), \\ degree of centralization, material flow (productive environment), whether it was \\ introduced as card-based, types of authorizations, number of articles published \\ and type of articles published (theoretical or empirical). Most new PCS's (7 out \\ of 13) show characteristics that are similar to Kanban, CONWIP and POLCA: \\ they are decentralized, card-based and use WIP as primary control variable. This \\ may be a result of the strong influence of Lean Manufacturing paradigms \\ Meanwhile, there is a general lack of empirical studies, being 11 PCS's \\ developed from mathematical simulations.
}

Keywords: card-based system; production system; production control system; production control; COBACABANA.

\section{Introduction}

Production Control Systems (PCS) are a key factor for effective manufacturing systems as they regulate the information and materials flows through the factory (Masin, Herer, and Dar-El 2005; Karrer, Alicke, and Günther 2012). Therefore, the choice of an appropriate PCS is an important success factor for any organization (Hassan and Kajiwara 2013). Consequently, many different PCS's emerged. This includes Kanban systems (e.g. Sugimori et al. 1977; Berkley 1992; Monden 1998; Lage Junior and 
Godinho Filho 2010); Constant Work-In-Process (CONWIP; e.g. Spearman, Woodruff, and Hopp 1990; Framinan, Gonzales, and Ruiz-Usano 2003; Prakash and Chin 2014; Jaeglar et al. 2017); Drum-Buffer-Rope (DBR; e.g. Goldratt 1990; Guide 1996; Mabin and Balderstone 2003); Periodic Batch Control (PBC; e.g. Burbidge 1996; Benders and Riezebos 2002); Materials Requirements Planning (MRP; e.g. Orlicky 1975; Mohebbi, Choobineh, and Pattanayak 2007); Workload Control (WLC; e.g. Land and Gaalman 1998; Land 2006) and Paired Cell Overlapping Loops of Cards with Authorization (POLCA; e.g. Suri 1998; Riezebos 2010).

For these 'classical' PCS, there is a large literature available. Some papers present a literature review of different PCS, for example Stevenson, Hendry, and Kingsman 2005, Liu and Huang (2009), Fernandes and Godinho Filho (2011) and Thürer, Stevenson, and Protzman (2017). There is also a large number of works comparing different PCS's by use of simulation, for example, Liu and Huang (2009), Koulouriotis, Xanthopoulos, and Tourassis (2010), Sato and Khojasteh-Ghamari (2012), Silva et al. (2017), and Thürer et al. (2019).

However, all of this literature focusses on PCS's developed before 1998, the year when POLCA emerged. To the best of our knowledge, there is no study that summarizes the main advances concerning PCS's in the last 20 years. Thürer, Stevenson, and Protzman (2017), for example, only included four card-based systems on their review (Kanban, CONWIP, POLCA and COBACABANA), of which only COBACABANA was developed in the last 20 years. In response, this study started by asking: What are the characteristics of Production Control Systems that newly emerged in the last 20 years? 
To answer this question, this study uses a Systematic Literature Review (SLR) to provide a review and discussion of new PCS's that emerged since 1998. Our definition of new PPC excludes extensions of classical PCS's (for example, variations of Kanban, CONWIP and POLCA) that do not significantly change the nature of the original system. Therefore, the systems included in this article either differ significantly from existing ones (such as COBACABANA) or combine elements and characteristics of two or more existing systems (such as BK-CONWIP and B-CONWIP).

All new PCS's identified in the SLR were included in this paper, although there is a great difference among them regarding evolutionary stage and number of articles published. They also vary according to their characteristics in terms of underlying structure. So, they all can provide interesting insights to the proposal of new PCS's as well as they can provided elements to understand why some PCS's have more implementation success than others. In terms of research, we seek to outline new search directions for future research on PCS's. In terms of practice, we hope that our study helps managers to find new solution to their day-to-day problems.

The remainder of this paper is organized as follows. Section 2 describes the research method used in this paper (SLR) and the main variables defined to compare different PCS's. In Section 3, the PCS identified in the SLR are described, with emphasis on how they work and the most suitable environments for each of them. Section 4 compares the PCS's identified in the SLR according to their evolution and the variables defined in Section 2. Finally, Section 5 provides some conclusion, limitations and suggestions for future research. 


\section{Systematic Literature Review}

A systematic literature review is considered the most adequate method to answer our question since it allows for understanding existing knowledge in more depth while minimizing bias in the selection of articles (Tranfield, Denier, and Smart 2003; Fawcett et al. 2014). The two subsections below outline the approach adopted for article selection and analyzes of the articles.

\subsection{Article Selection}

Article selection followed the four steps proposed by Tranfield, Denier, and Smart (2003) and used in many articles, like Negrão, Godinho Filho, and Marodin (2017), which are:

- Step 1 - Search in database: following Chadegani et al. (2013) and Thomé, Hollmann, and Scavarda (2014), we first conducted search in five databases (Web of Science, Scopus, Google Scholar, Emerald Cite and Engineering Village). Initial research strings were defined based on keywords used in an initial set of papers on COBACABANA, DEWIP, Demand Driven Materials Requirement Planning and REDUTEX. The strings production control systems, production systems, production control and card-based were selected. However, after some initial searches in the databases, we decided to further limit search results by adding additional words to the search strings, due to the large number of unrelated articles (Table 1). Therefore, again looking at the initial papers, we added production, push and pull to the original strings, as presented in the research protocol. The research was limited to articles written in English and resulted in 7.870 non-duplicated articles. 
- Step 2 - First filter: The title and the summary of the 7.870 articles were evaluated in order to assess whether they met inclusion and exclusion criteria of the research protocol. As our objective is to identify PCS's proposed from 1999 to 2018 , papers which only review systems developed before 1999 were excluded. Papers which presents evolution of classical systems were also excluded because these systems do not match the definition of new PCS's presented in the introduction of this article. We also excluded all articles on planning and scheduling given our focus on production control. Therefore, our inclusion criteria are papers which present proposals of new PCS's (theoretical, simulation or empirical) or that compared PCS's in which at least one of them were developed from 1999 to 2018 . The first filter resulted in 218 articles.

- Step 3 - Second filter: This filter consisted of a full reading of the 218 remaining articles, again applying the inclusion and exclusion criteria defined in the research protocol. The second filter resulted in 24 articles. These three steps are summarized in Figure 1.

- Step 4 - Final Selection: To the 24 articles selected, 12 were added using the snowball approach, resulting in 36 articles. Some articles were identified by citations in the 24 articles that resulted from the SLR. Others were included by searching for the name of the PCS's identified in the databases. The snowball approach added a large number of articles to this review because many papers use specific key words to propose new PCS's, such as lot release rule, manufacturing control, production line control, materials management, among others. Therefore, we were not able to define a group of keywords that would systematically result in most of the 36 articles in the initial search. 
Table 1. Research Protocol.

\begin{tabular}{ll}
\hline & \multicolumn{1}{c}{ Research Protocol } \\
\hline & Web of Science, Scopus, Google Scholar, Emerald Cite and \\
Database & Engineering Village \\
Publication Years & From 1999 to 2018 \\
Document type & Journals \\
Language & English \\
Strings & "production control system*" \\
& "production system" AND "push*" \\
& "production system*" AND "pull" \\
& "card based" AND "production" \\
& "production system" AND "hybrid" \\
& "production control" AND "pull" \\
& "production control" AND "push*" \\
- Articles featuring a new PCS \\
- Applications or comparisons of PCS's developed over \\
- the last 20 years \\
- Evolution of classical systems, such as Kanban and \\
Exclusion criteria & CONWIP; \\
& - Application of sequencing rules to prioritize production; \\
& - Review literature of existing PCS \\
\hline
\end{tabular}

Figure 1. Systematic Literature Review.

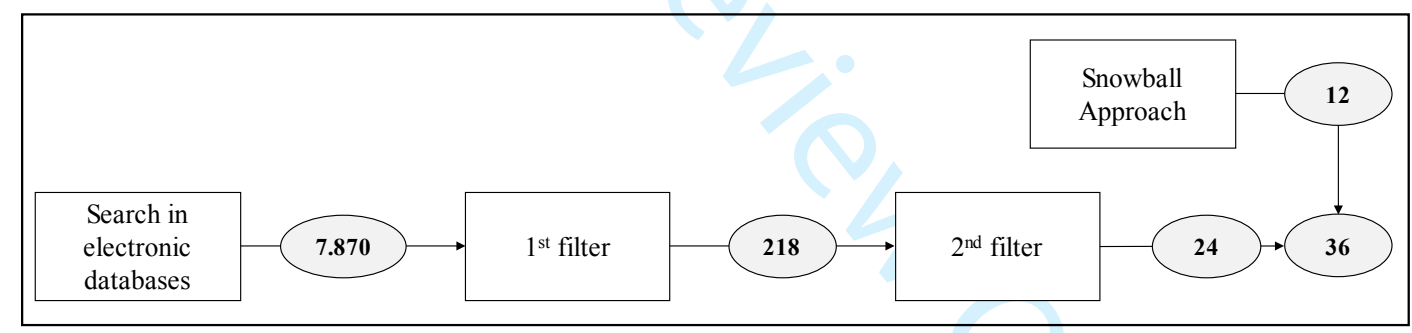

\subsection{Article Analysis}

This stage involved extracting and documenting information from the 36 sources. To minimize subjectivity, the authors: (i) cross-checked results; and, (ii) conducted regular meetings to resolve any emerging inconsistencies in interpreting the results. From our sample, 13 PCS's were identified.

As a template for data collection, a simple matrix was used where, for each PCS (row), we asked (column): 
- What are the characteristics of the system?

- How does the system work?

- In what productive environments did this system prove useful?

- What research was available involving the system?

To compare the 13 PCS's, two dimensions were selected: systems' characteristics and evolution. Regarding systems' characteristics, five variables were selected, as follows:

(1) Primary Control Variable: a system can either control WIP or throughput. If a PCS control WIP, then it observes throughput. The opposite is also true (Hopp and Spearman 2008);

(2) Degree of Centralization: if order release is controlled by a central entity (e.g. production planner), then the PCS is Centralized. An example of a classical centralized PCS is MRP, as all orders are release by production planning. Local stations only execute the order. On the other hand, some systems are Decentralized, because the local production stations are responsible for defining when to start an order and even which order to start. This occurs, for example, in Kanban. In some PCS, there are more than one type of release authorizations. For example, in BK-CONWIP, an order is processed only if received CONWIP, Base Stock and Kanban authorization. It is possible that some of these authorizations are centralized and some are decentralized. Therefore, those systems are classified as hybrid. For example, in BK-CONWIP, Kanban authorizations are decentralized (locally controlled by production stations), but CONWIP and Base Stock authorizations are centralized (controlled by the central production planning). 
(3) Applicability to material flows: it is important to understand to what kind of environment a PCS is more suitable for in order to choose a more adherent system to the environment analysed. An important variable in the shop floor is the flow of materials. Some PCS's are more suitable to flow shop (flow of items occur in the same direction) and others to job shop (flow of items occurs in different direction) (Johnson and Montgomery 1971). However, in some cases, although a PCS is more adequate to a certain type of flow, it can also be applied in the other. An example is COBCABANA, initially proposed for job shops, but in later papers simulated successfully in flow shops;

(4) Card-based system: a PCS is classified as card-based if it was originally introduced based on card signals. But note that these signals can also be other physical entities (such as boxes) or even electronic signals (Thürer, Stevenson, and Protzman 2017). As DSSPL, DSSPL, DDMRP and REDUTEX were introduced using cards to trigger the work of some items or some production stages, they are classified as partially. As cards are used to control the stock or workload levels of the systems, not the throughput, all card-based systems identified in the review have WIP as primary variables. The opposite, however, is not true (all systems that have WIP as primary variable are not card-based). CONLOAD is an example, as it controls WIP, but does not use cards;

(5) Types of order authorization: to release orders in production floor, an authorization is necessary. Some systems have only one type of authorization, such as COBACABANA, in which system workload is controlled by cards that determines if an order could enter the shop floor or not. On the other hand, other systems have more than one type. For example, in BK-CONWIP, an order enters the shop floor only if it has 3 types of authorization (Basestock, Kanban and 
CONWIP authorization). Therefore, besides the number of authorizations, we added the word simultaneous in Table 2 for those systems. Finally, there are systems with more than one authorization in which the first authorization concerns a group of items and a second authorization concern another group. This is the case of Demand Driven Materials Requirement Planning (DDMRP), in which some systems are planned based on MRP (Materials Requirement Planning) explosion while others are controlled by stock reposition (as explained in Section 3.10).

The first and second variables (primary control variable and degree of centralization) are presented by Lödding, Yu, and Wiendahl (2003). The third (material flow) is adapted from Löoding, Yu, and Wiendahl (2003). Originally, these authors classified the system flow complexity into high and low. However, given the predominance in literature of job shop and flow shop concepts, we will use these classes for the intermittent systems presented, as proposed by Johnson and Montgomery (1971). The two classifications, however, are integrated, since the materials flow of a job shop system is more complex and that of a flow shop is simpler. The fourth variable (cardbased systems) was included, given the importance card-based systems received over the last two decades in the literature and its wide application in practice given its low initial investment compared to electronic systems, its implementation simplicity and the benefits of visual control (Liberopoulos and Dallery 2000; Thürer, Stevenson, and Protzman 2017). Finally, the fifth variable is a fundamental characteristic of PCS.

Finally, also understanding the evolution of the PCS's is important. To capture evolution, two variables were selected:

(1) Number of articles published about a PCS's: we considered only papers that contribute clearly to the development of a PCS by a mathematical simulations, 
empirical application or comparison with other systems. Therefore, papers that only cite the system were not considered in the evolution analysis; and,

(2) Type of paper published: we classified the papers published about each system into axiomatic or empirical, following the classification of Operations Management papers proposed by Bertrand and Fransoo (2002). This variable was important to further analyse how close are literature and practice regarding the new systems identified.

\section{Results: New Production Control Systems (PCS)}

This section introduces each of the PCS identified from the literature. A summary discussion comparing the different PCS's across our system characteristics and system evolution dimension is then presented in Section 4.

As many of these systems are based on cards, value stream mapping (VSM) schematics were used in many of the following figures to help understanding how each PPC works. In VSM, circles represent workstations, triangles the stock points and full arrows the material flow. Other symbols will be explained in the legend of the figures in which they are used.

\subsection{Inverse Base Stock}

Little explored in literature, Inverse Base Stock (IBS) was proposed by Masin, Herer, and Dar-El (1999). Apart from its conceptual proposal, there is no other study about IBS in literature. Therefore, this system stops at a very early stage.

IBS is part of the self-regulated WIP (SWIP) approach, also proposed by Masin, Herer, and Dar-El (1999), which unifies several PCS's such as Kanban, CONWIP, 
Drum-Buffer-Rope (DBR), Base Stock, among others. The main feature of SWIP is to group a set of equipment into a subsystem that shares the same number of containers or cards. In CONWIP, for example, the entire system shares the same number of containers, while in Kanban each pair of adjacent workstations is a subsystem.

The name Inverse Base Stock is due to the visual representation of this system, which is the mirror image of Base Stock (Figure 2). IBS releases a job on the first station only if cards are available for processing that order at all stations in the system. After being processed in a station, the order releases the card of that station.

Figure 2. Base Stock and Inverse Base Stock.

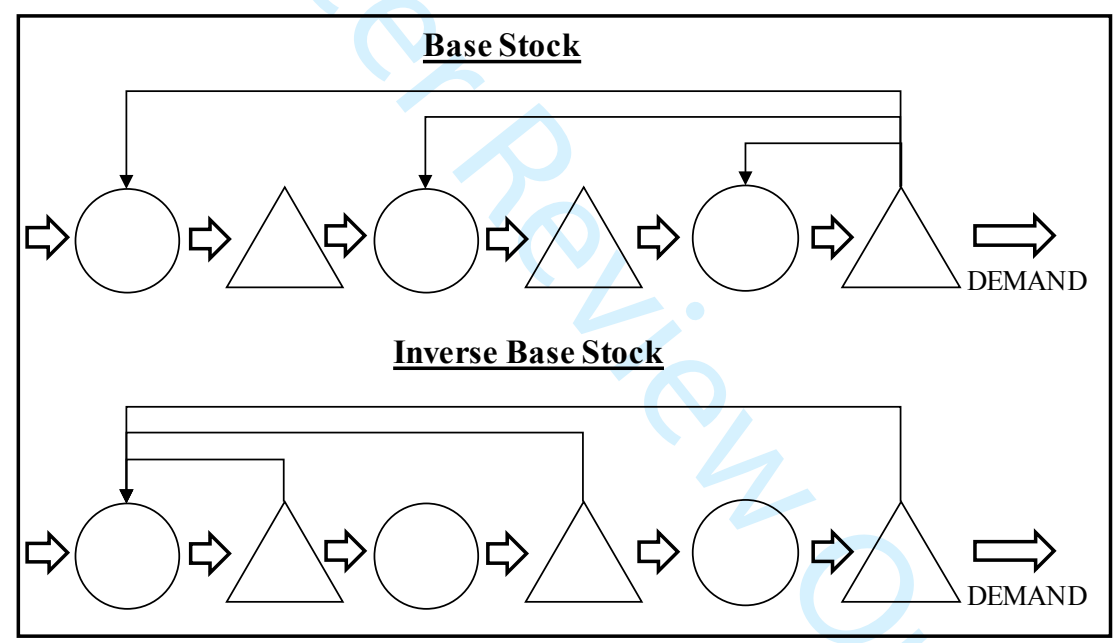

Source: Adapted from Masin, Herer, and Dar-El (1999) and Masin, Herer, and Dar-El (2005).

\subsection{Customised token-based systems}

Proposed by Gaury, Pierreval, and Kleijnen (2000), the Customized token-based systems (CTBS) is a generalization of token-based systems, which generally use cards as token (Gonzáles-R et al. 2007). According to Liberopoulos and Dallery (2000), this class of PCS is the easiest to implement and the most studied in the literature. As shown 
in Figure 3, CTBS considers all possible relationships between workstations (e.g., k23 is the looping between workstations 1 and 2). Specific systems, such as the CONWIP (loop k13 - between the first and last station), are CTBS special cases (Gonzáles-R et al. 2007).

Figure 3. Customised token-based systems.

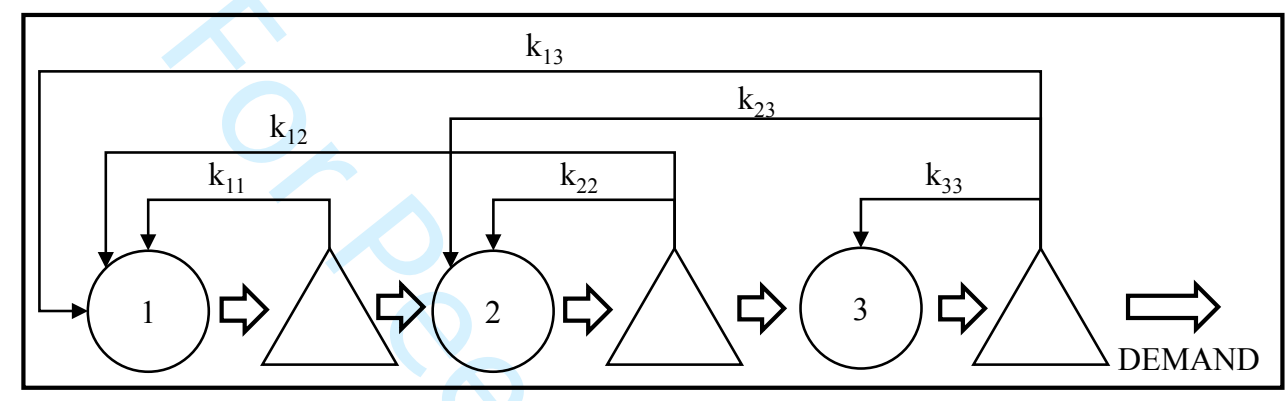

Source: Adapted from González-R et al. (2007).

In general, the selection of a PCS is based on an a priori approach, which means that a PCS is selected without considering the specific characteristics of the factory floor, such as processing times, set-up times, demand, machines workload, among others (González-R and Framinan 2009). CTBS, on the other hand, is based on a posteriori approach, which starts from a generic system that is shaped from the environmental knowledge. Therefore, CTBS consider all the space solutions in order to choose the best set of parameters (all possible loop structures and how many cards to keep in each of them).

To give an example, if CONWIP was chosen as the PCS, then only loop k13 will exist. Therefore, the task is to define how many cards to maintain in this loop. In an a posteriori approach, on the other hand, it is considered which loop structures should exist and how many cards to keep in each of them. González-R and Framinan (2009) accomplish this task using the cross-entropy method. 
After its conceptual proposal, this system was further developed by Gonzales-R et al. (2007) and Gonzáles-R and Framinan (2009) which compared CTBS with other systems by simulation and proposed a method to develop the a posteriori approach using cross-entropy. However, no empirical study of this system was reported in literature.

\subsection{Behaviour-Based Control}

The Behaviour-Based Control (BBC) system was proposed by Paternina-Arboleda and Das (2001). BBC is based on the reinforcement learning concept, in which decisionmakers learn optimal control policies by receiving rewards and punishments as a result of their actions. Therefore, decision-maker chooses actions to maximize their rewards over time (Kaelbling, Littman, and Moore 1996)

The system has three types of authorizations (Figure 4):

- CONWIP authorization: whenever a demand is met, the CONWIP card returns to the first stage, authorizing the production of a new item.

- Kanban authorization: at all except for the last stage, there are kanban cards to restrict the buffer between stages.

- Emergency authorization: whenever a demand is not met or a machine breaks, an emergency authorization card is released. This card authorizes the production of an additional unit and cannot be reused.

Using simulation, Paternina-Arboleda and Das (2001) showed that in a repetitive flow shop environment, BBC presents better performance than other systems, such as Kanban, CONWIP Base Stock, Extended Kanban Control System (EKCS) and two- 
boundary hybrid control. However, this system was also not further developed and lack empirical studies to prove it can be useful in practice.

Figure 4. Behaviour-Based Control authorizations.

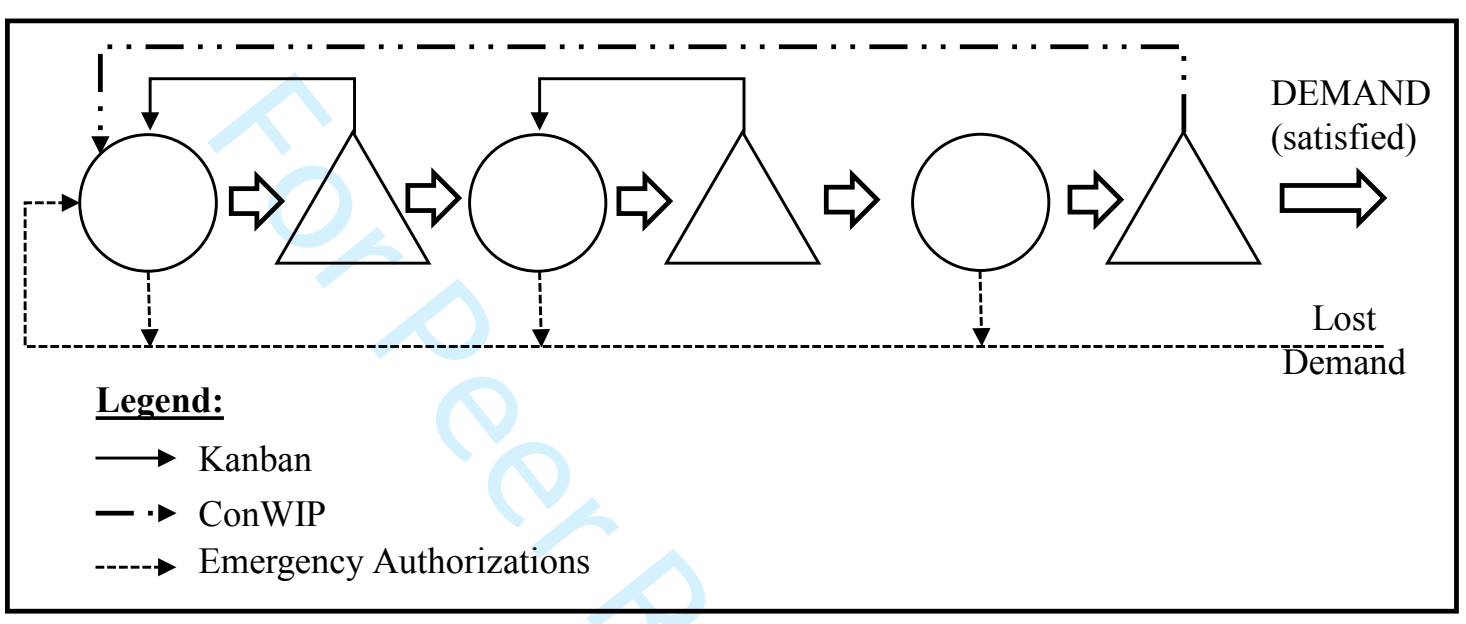

Source: Adapted from Paternina-Arboleda and Das (2001).

\subsection{Gated MaxWIP}

Gated MaxWIP (G-MaxWIP) is a hybrid PCS proposed by Grosfeld-Nir and Magazine (2002) in which all production stages are pushed, except for the first, which is pulled. The main characteristics of this system is that the first production stage is used as gate (Figure 5). This gate controls the entrance of materials into the system based on the system WIP. If WIP is below a certain defined level, the gate stays opened and lets materials enter the system. When WIP reaches a pre-set maximum WIP level, the gate closes. Then, two strategies can be used to open the gate: as soon as the WIP reaches a certain level or after a certain time interval. 
According to Grosfeld-Nir and Magazine (2002), G-MaxWIP combines two of the most desirable features of PCS. The first one (pull) is to control the system WIP by opening and closing the gate. Regarding this point, G-Max WIP and CONWIP work similarly. The second one (push) is to allow resources to work unrestricted, increasing utilization. This is true, unless when the gate is closed. In this moment, some stages can become idle due to the lack of material to be processed (Sepehri and Nahavandi 2007).

Figure 5. Gated MaxWIP.

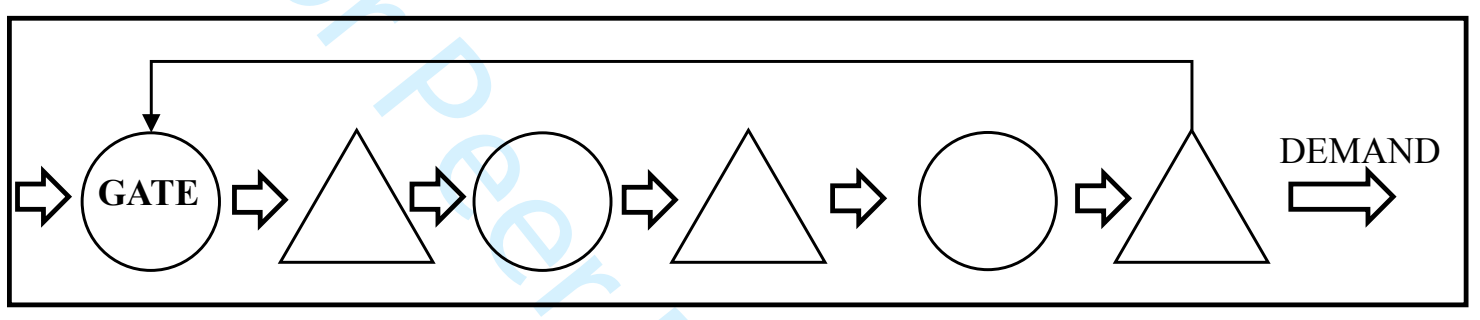

Sepehri and Nahavandi (2007) compared G-MaxWIP with CONWIP and

CWIPL (critical WIP loops) through simulation studies, however no other development of this system was found in literature. Moreover, G-MaxWIP also lacks empirical studies.

\subsection{Parallel Pull Flow}

Based on Lean principles, Parallel Pull Flow (PPF) was developed by Hunter et al. (2004) and it was not found any other reference to this system in literature, apart from Hunter (2006) and Lasa, Vila, and Uriarte (2009). Developed originally for furniture and wood components industry, PPF consists of a return-loop (rectangular or oval configuration), in which one side is used for kitting and staging carts and the other for final assembly. 
When an item is assembled, the container returns empty to the purchased components area, where the necessary components for the assembly of the next final product are collected (Figure 6). The container also collects the required semi-finished items produced in subassembly lines. With all the necessary components, the container enters the assembly line and a sequence of activities is performed. Once the item is assembled, the final product is delivered and the container returns empty to the component area, collecting the necessary components for the next order (Hunter 2006).

Figure 6. Parallel Pull Flow.

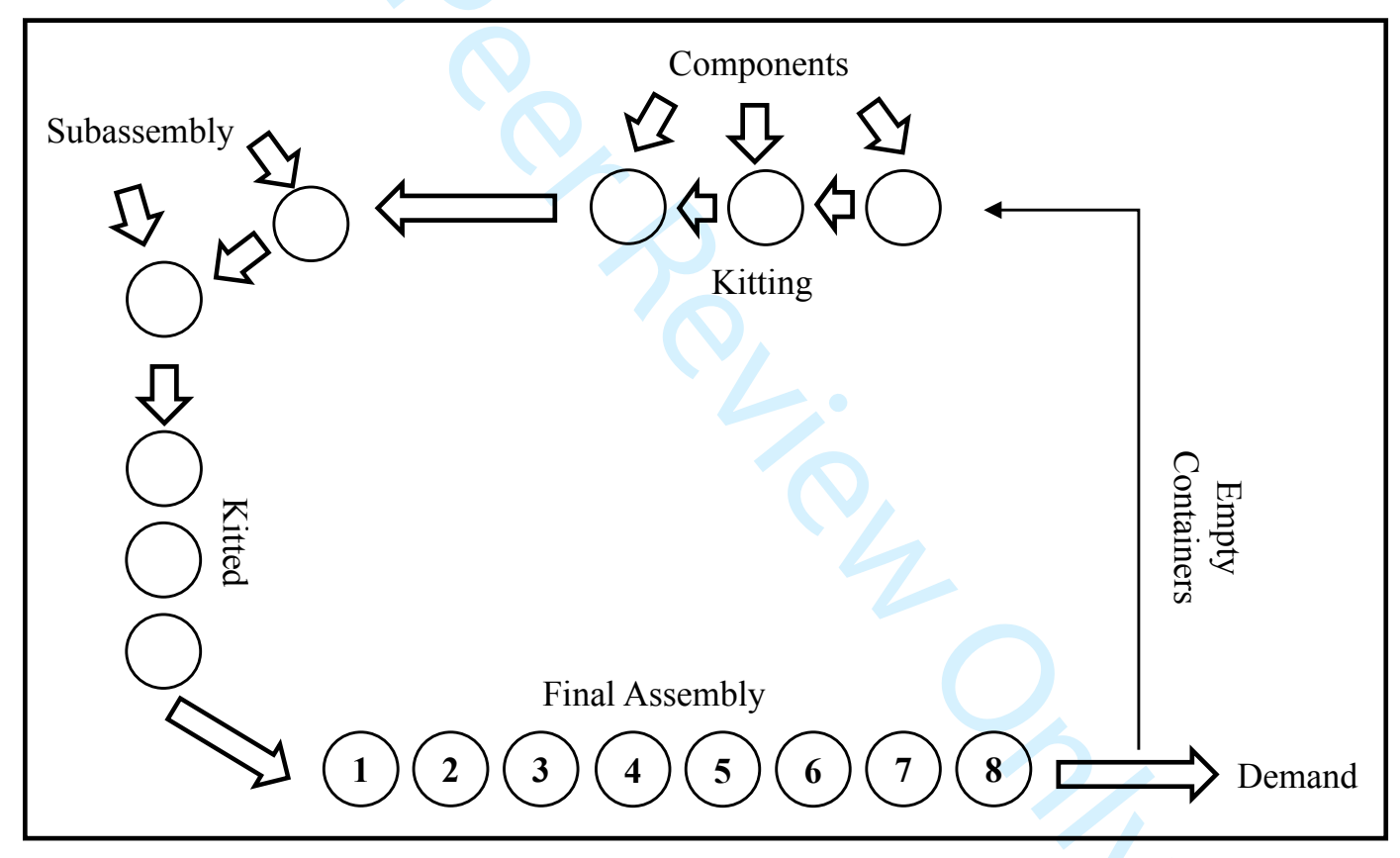

Source: Adapted from Hunter (2004).

This system, little explored in practice and literature, is argued to be useful for environments where component availability is critical. The coordination between the subassembly lines and the assembly line can be performed by another PCS. Hunter et al. (2004) suggests the use of Kanban systems. 


\subsection{Control of Balance by Card Base Navigation}

COBACABANA, an acronym for Control of Balance by Card Based Navigation, was proposed by Land (2009) and refined by Thürer, Land, and Stevenson (2014). Unlike other card-based systems, COBACABANA uses the Workload Control approach, releasing orders based on the workload of critical stations (Thürer, Stevenson, and Protzman 2017). Therefore, COBACANABA creates a card loop between the central planner and critical workstations (Figure 7). Note that this loop structure is similar to the IBS system discussed in Section 3.1 above.

Figure 7. COBACABANA card loop.

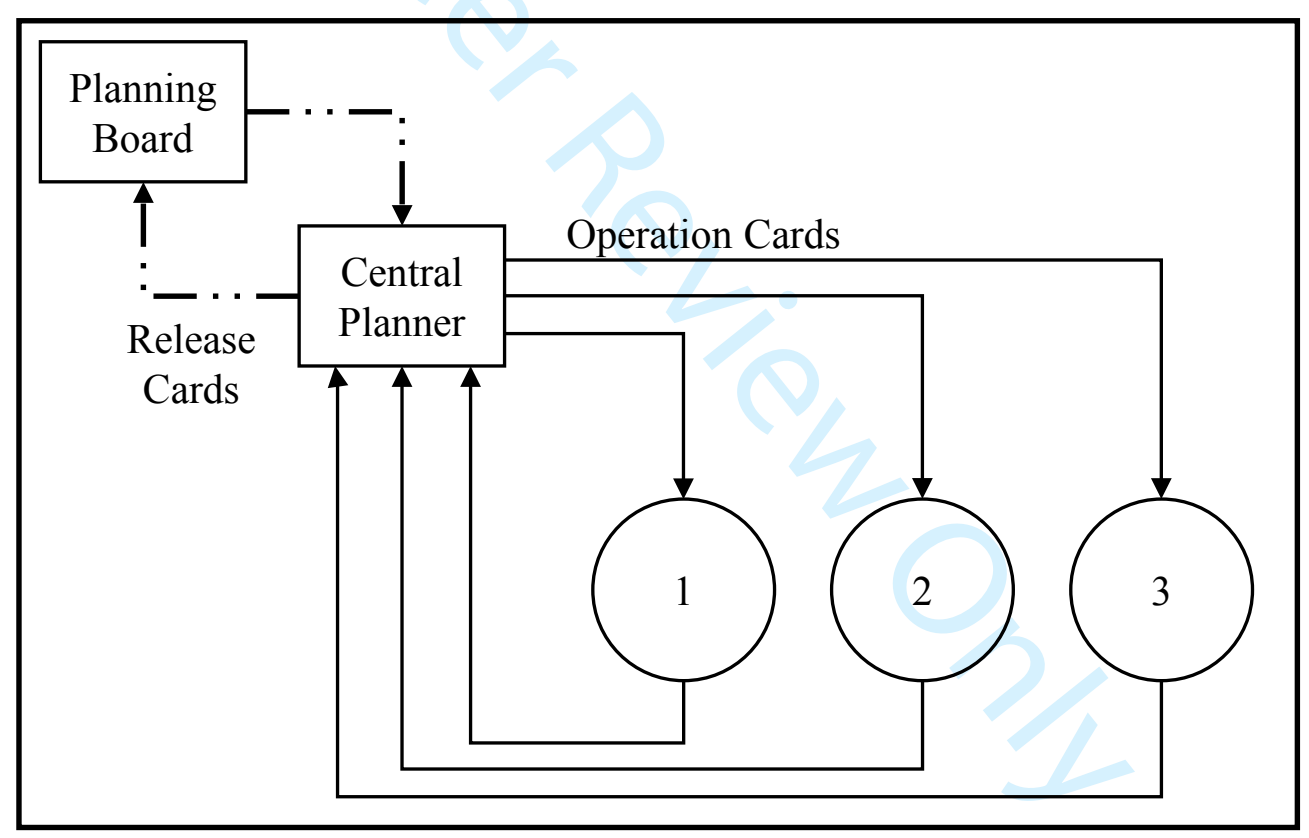

Source: Adapted from Thürer, Land, and Stevenson (2014).

By controlling the workload at stations, COBACABANA also focuses on controlling the throughput times of each station (Land 2009). COBACABANA uses a pair of cards: 
- Release card: this card stays with the central planner and is used to calculate the workload in the shop-floor.

- Operation card: this card goes to the shop floor with the released order and return to the central planner after an operation is complete.

COBACABANA uses a centralized release orders function called pre-shop pool. In this pool, orders are sorted according to their due date (Thürer, Land, and Stevenson 2014). Before releasing an order on the shop floor, the planner evaluate whether this order will not exceed the capacity limits set for critical stations. If the order violates these limits, the planner considers releasing the second order and so on, until all the orders in the pool were considered.

To assess if there is available capacity at the stations, the planner compares the current workload with the workload limits on the planning board (Figure 8). For each operation card release, a release card (of the same workload) is placed on the board. Each time an operation card returns to the planner, a release card with the same workload is removed from the board.

According to Thürer, Stevenson, and Protzman (2017), orders in COBACABANA can be released periodically (Original COBACABANA) or continuously (Continuous COBACABANA). In the first case, orders are released at fixed time intervals or also releases an order without load considerations whenever the first station in the routing of the order is starving. In the second case, release decisions are taken whenever an operation is completed or a new order arrives at the pre-shop pool.

Regarding the environment, COBACABANA was originally proposed for highvariety job shop contexts, but studies show a good system performance even in pure 
flow shop (Thürer, Stevenson, and Protzman 2015). However, to the best of our knowledge, there is no empirical study of this system was reported in literature.

Figure 8. COBACABANA planning board.

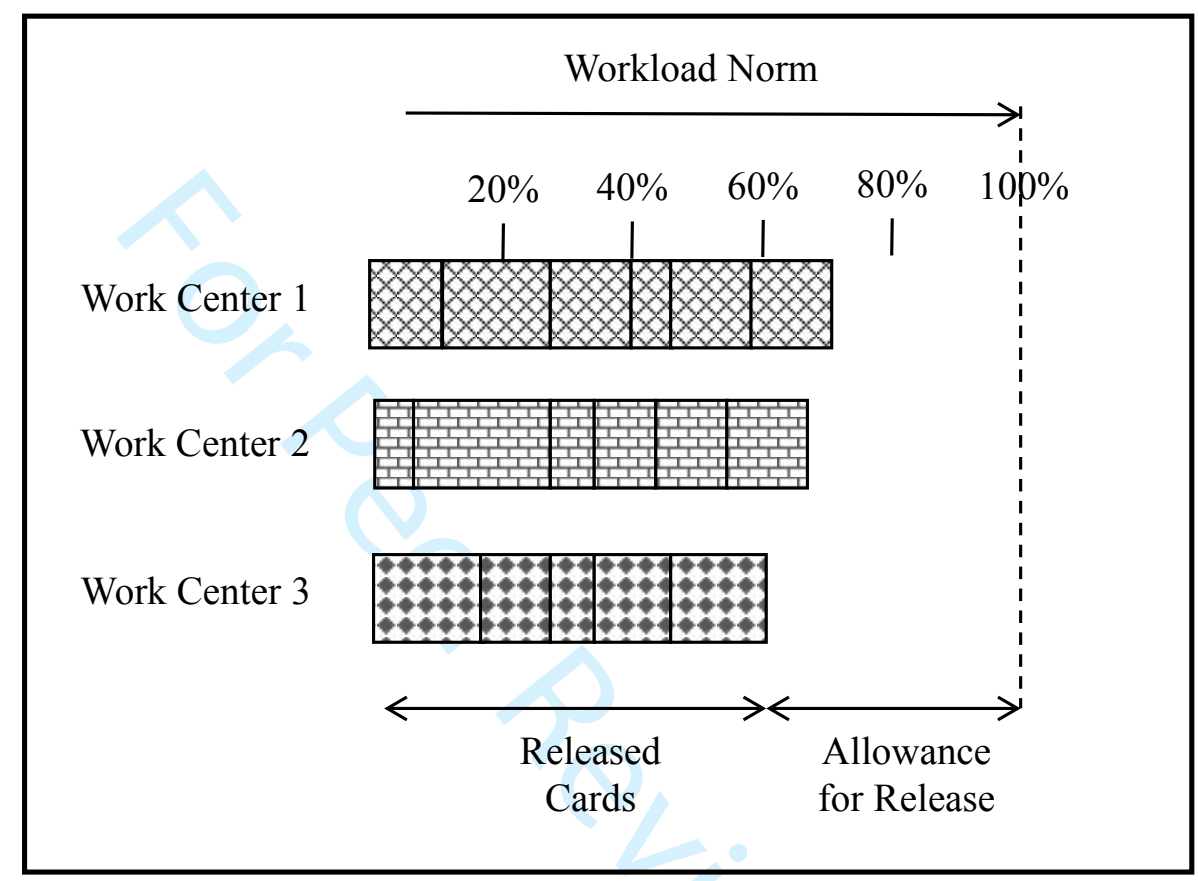

Source: Adapted from Thürer, Land, and Stevenson (2014).

\subsection{Basestock Kanban-CONWIP}

BK-CONWIP was developed from HK-CONWIP (Hybrid Kanban-CONWIP). The HK-CONWIP was proposed by Bonvik, Couch, and Gershwin (1997), with the aim of offering a system that would respond to an environment with a greater variety of products, controlling the total inventory of the system (CONWIP cards), but also the stock of each stage, except the last one (Kanban cards). Therefore, two production authorization cards are used. Several studies show that HK-CONWIP performs better Kanban and CONWIP, such as Geraghty and Heavey (2004) and Wang, Cao, and Kong (2009). HK-CONWIP was originally developed for a single product and several studies 
have assumed the possibility of replicating it for various products (Onyeocha et al. 2015).

In a multi-product PCS, two different authorization policies can be used: Shared Kanban Distribution Policy (S-KDP) or Dedicated Kanban Distribution Policy (D-KDP) (Bayant, Byzacott, and Dallery 2002). While in D-KDP each card is specific to authorize the production of a single product, in S-KDP a card can be shared by a set of items (in this policy, the specific item to be produced is selected according to demand and materials availability). This makes S-KDP more flexible to variations in demand than D-KDP.

As shown by Bayant, Buzacott, and Dallery (2002), Onyeocha and Geraghty (2012) and Olaitan and Geraghty (2013), several pull systems such as Kanban, CONWIP, Base Stock and HK-CONWIP have a bad performance when operating SKDP in a multi-product environment, due to the method they adopt to transmit demand variations to the system. In this context, Onyeocha and Geraghty (2012) proposed the Basestock Kanban-CONWIP (BK-CONWIP) as an alternative to HK-CONWIP, in order to allow this system to work with the S-KDP policy. As Onyeocha, Khoury, and Geraghtu (2015) state, BK-CONWIP is suitable for environments with high production mix flexibility and can operate with both the S-KDP strategy and the D-KDP strategy.

In BK-CONWIP, demand information is globally transmitted to all production stages (Onyeocha et al. 2015). The system has three control parameters (CONWIP cards, Kanban cards and Stock levels). As well as in the HK-CONWIP, CONWIP authorization cards are used to control the stock of the whole system and Kanban authorization cards to control the inventory on each stage. The Base Stock level in finished products is used to control the overall flow of demand information into the system. 
When an order enters the system, demand information is sent to all production stages and special information to the last stage, so that it releases a CONWIP card to satisfy the demand. If raw materials and capacity are available, production starts simultaneously at all stages. If not, production starts, but is interrupted at the stage with capacity restriction or lack raw materials. As soon as the final product arrives in stock, the CONWIP card returns to the buffer (Figure 9).

Figure 9. BK-CONWIP.

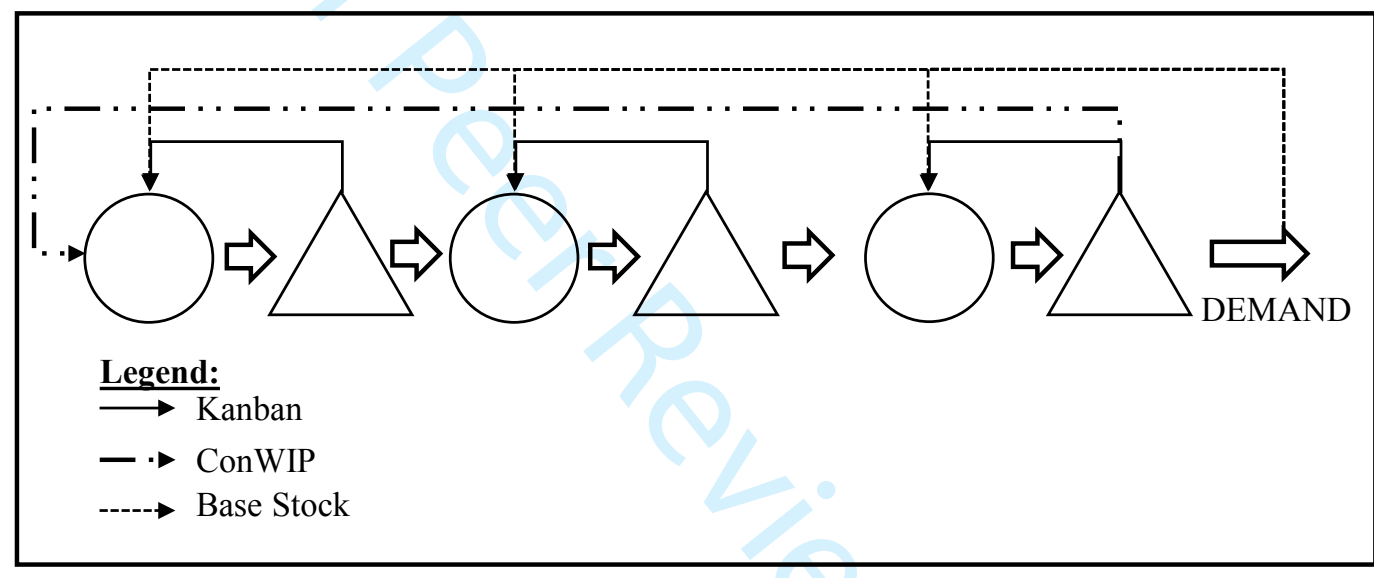

Apart from Onyeocha and Geraghty's articles, other references to BK-CONWIP are restricted to conferences. However, this system presents an interesting initial evolution, which includes a simulation study (Onyeocha et al. 2015). However, this system also lacks empirical studies in order to understand how it will react to real production environments.

\subsection{Basestock CONWIP}

The Basestock-Constant Work-In-Process (B-CONWIP) was proposed by Hawari, Qasem, and Smadi (2018) from BK-CONWIP. Apart from its proposal article using 
simulation, no other reference to B-CONWIP was found in literature. The objective of this system is to minimize WIP and to achieve specified service levels. Like BK-

CONWIP, B-CONWIP can operate with S-KDP and D-KDP policy, and has two control parameters:

- Base Stock levels: Minimum inventory level at each stage so that it meets all unanticipated demand.

- CONWIP authorization card: limits WIP throughout the system.

The main difference between BK-CONWIP and B-CONWIP is that B-CONWIP does not use kanban cards between the stations (Figure 10). A balancing algorithm to control the stock of each productive stage is uses instead. According to Hawari, Qasem, and Smadi (2018), the control of WIP levels of both systems is similar, with the advantage of B-CONWIP being simpler, especially in environments with many productive stages and many products.

Figure 10. B-CONWIP.

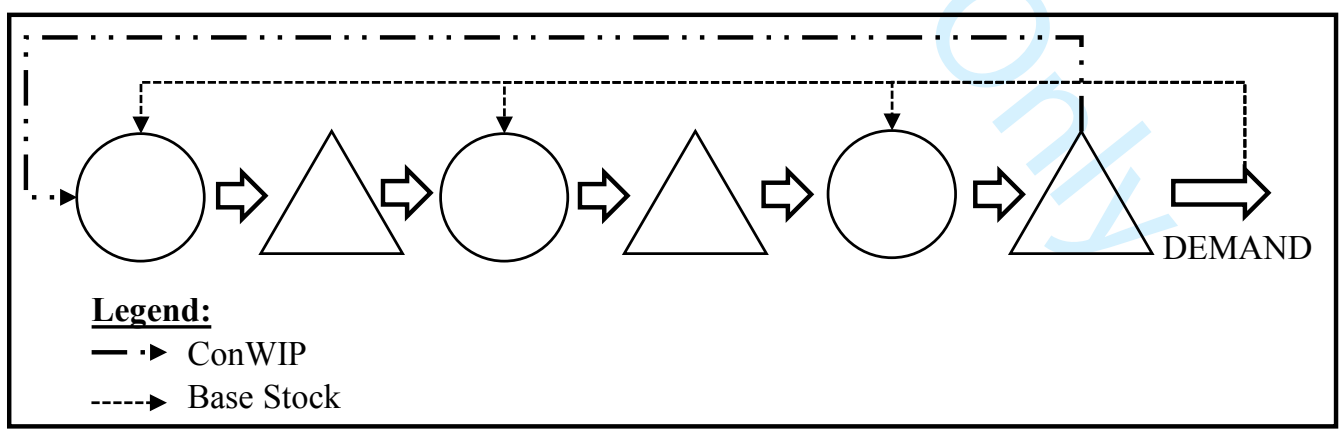

The authors also claim that when demands increase, B-CONWIP is more appropriate if the priority is the service level, while BK-CONWIP is the best option if WIP control is the most important variable. 


\subsection{Double Speed Single Production Line}

The Double Speed Single Production Line (DSSPL) is a hybrid PCS proposed by Stagno, Glardon, and Pouly (2000). It was developed for industries with many distinct products (and small variety among them) and a wide variation in demand. Its main distinction from others PCS is its selectivity in allocating products to resources. Items are segregated into two groups:

- A-products: small number of products, with high production volume and fairly regular demand.

- B-products: large number of products, sold in small quantities and with irregular demand.

In DSSPL, items A are produced quickly through a pull system and items B are controlled by a push system (Figure 11). Through this segregation, it is possible to reduce lead time and stock levels of items A without significantly affecting items B. However, since items A correspond to a high volume, this change has a significant impact on the overall system result. An application of DSSPL is presented by Cheikhrouhou, Hachen, and Glardon (2009). 
Figure 11. DSSPL.

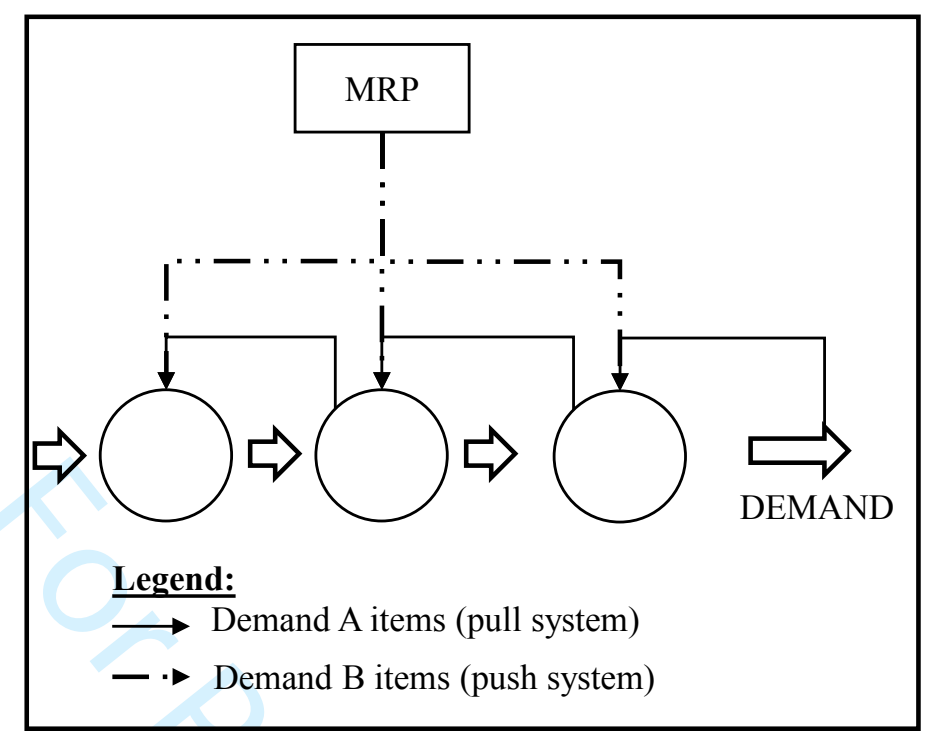

Source: Adapted from Cheikhrouhou (2007)

\subsection{Demand Driven Materials Requirement Planning}

Demand Driven Materials Requirement Planning (DDMRP) is a hybrid PCS proposed by Ptak and Smith (2011). This system aims to combine the best practices of MRP II, Lean Manufacturing and Theory of Constraints (Miclo et al. 2018). According to Miclo et al. (2016), DDMRP has been developed since 2000 and has already been implemented in some United States companies. In literature, empirical and simulation articles of DDMRP can be founded.

DDMRP is based on four basic principles (Ptak and Smith 2016):

- Decoupled Lead Time: Some pre-defined Bill of Materials components are kept in stock (in Figure 12, items D and F are kept in stock);

- Decoupled Explosion: For components held in stock, the requirements are not generated by the traditional MRP explosion, but by the ASE; 
- Available Stock Equation (ASE): calculated daily, projects future stock based on actual demand (not forecast) and orders in production. The ASE is compared to 3 buffer levels: red (safety stock), yellow (every time the ASE reaches the yellow zone, a new order is released for the stock to reach the top of the green zone) and green (replenishment size);

- Relative priority: colour of the card according to the zone in which the item is located. The orders also show a percentage of the stock projected by the ASE vs maximum stock of the item (top of the green zone).

Figure 12. DDMRP.

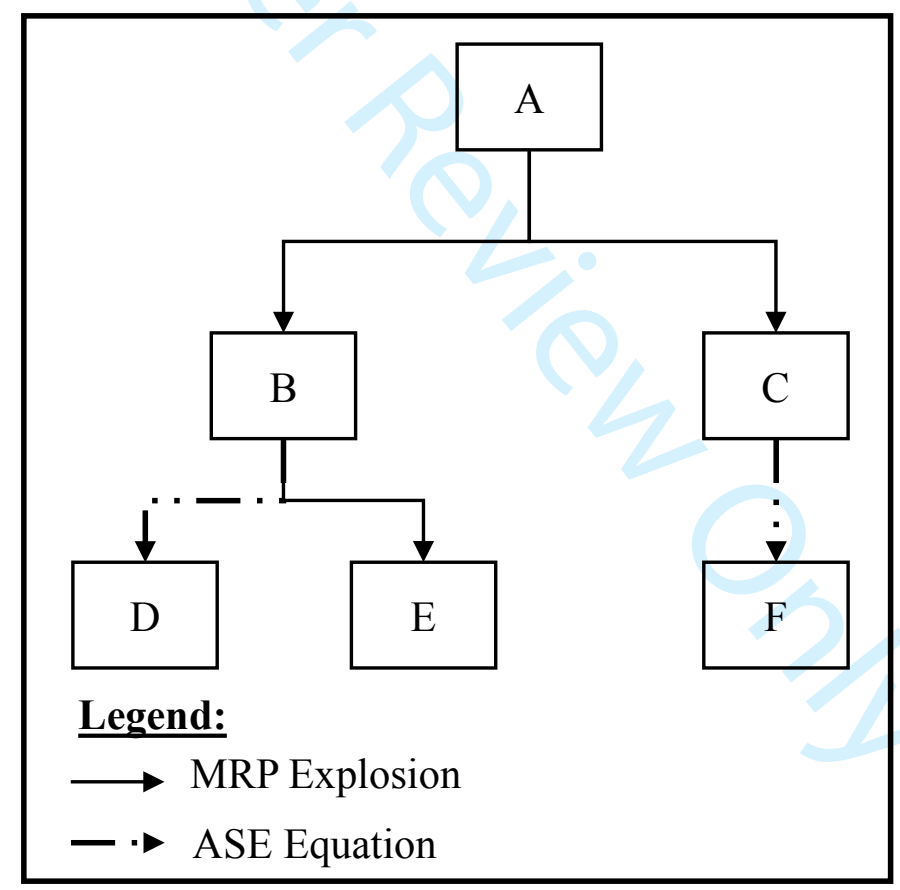

According to Ptak and Smith (2011), the implementation of DDMRP occurs in 5 steps. They are divided into: modelling the environment (Steps 1, 2 and 3), Plan (4) and Execute (5). The stages are: 
(1) Strategic Inventory Position: to evaluate, from a financial point of view, if an item of the Bill of Materials should or not be maintain in stock. The main function of the buffer is to absorb variability. Therefore, unlike a normal MRP, in DDMRP unbuffered items are pushed, but buffered items are pulled, replenishing inventory.

(2) Buffer Profiles and Levels: to size green, yellow and red zones based on the following equations:

- GreenZone $=$ Max (YellowZone $\mathrm{x}$ Lead Time Factor; LotSize $)$

- YellowZone $=$ ADU $\times$ ASRLT $\times$ PAF

- $\quad$ RedZone $=$ YellowZone $\mathrm{x}$ LTFactor $\mathrm{x}(1+$ Variability Factor $)$ Which:

- ADU (Average Daily Usage): daily average demand, estimated by demand forecast;

- ASRLT (Actively Synchronized Replenishment Lead Time): the longest unprotected sequence, considering the sum of lead time of the bill of material, of a buffered article.

- PAF (Plan Adjustment Factors): used to raise or lower the ADU, allowing to smooth seasonality. It should be defined based on the master plan capacity analysis.

(3) Dynamic Adjustments: to adjust the zones with changes in sales forecast.

(4) Demand Driven Planning: to create production and purchase orders.

(5) Visible and Collaborative Execution: to control the orders generated. 


\subsection{REDUTEX}

REDUTEX is a hybrid system developed by Serrato (2016) which aims to reduce customer lead time. It consists of 8 steps and is based on Lean (steps 4, 5 and 8) and Theory of Constraint (steps 1, 2, 3, 4 and 6) principles. Step 7 is particular of REDUTEX. The focus of the system is small and medium enterprises (SME) in which low technological knowledge is used (Teng and Jaramillo 2006); for example, the textile industries in Central Mexico.

The sequence of REDUTEX steps are:

(1) Identify the Restrictive Resource Capacity (RRC): to identify the resource that need to work with $100 \%$ of the daily capacity to meet demand;

(2) RRC optimization: to optimize the set ups in the RRC to increase the total production of the system;

(3) Synchronize rhythm with the RRC: all other resources must work at the same pace of the RRC. To do this, is necessary to adjust work shifts. Half shifts can be used (half of the time on one equipment, half on another);

(4) Create a smooth and continuous flow throughout the process: material must flow gradually into the system and there should be no accumulation of inventory between departments. To do so, it is essential to define an appropriate transference batch between processes (Figure 13);

(5) Create a supermarket: The supermarket at REDUTEX system is based on the concept that the more, the better, because it ensures RRC to work at full capacity. All resources before the supermarket (RRC included) are pushed and the ones after it are pulled;

(6) Create a time buffer: The time buffer is usually located before an assembly department and is a protection against fluctuations and delays in previous 
processes. In the example of Serrato (2016), it is located together with the supermarket. The time buffer purpose is to ensure that the components necessary to next day program are available. If not, the supervisor must verify at which point of the process they are and which actions are necessary to make them available at the assembly time;

(7) Control production through automated dual card system control: the system uses cards to identify and track products in the factory. The card follows the flow of the product throughout the entire factory and is transferred to the next department when the entire lot has been processed in the previous one. Regarding the card design, the right side contains barcodes and the left side information about each department. The card specifies product's type, size, colour, department, production lot, transfer lot and operator;

(8) Visual quality control: in a board for each department, the results of batch inspection are visually displayed. A green point indicates a batch that meet specifications, yellow one within specifications limit and red a batch that does not meet specifications. Serrato (2016) suggests organizing the board in this way: columns (types of defects evaluated) and lines (batches evaluated).

Figure 13. REDUTEX.

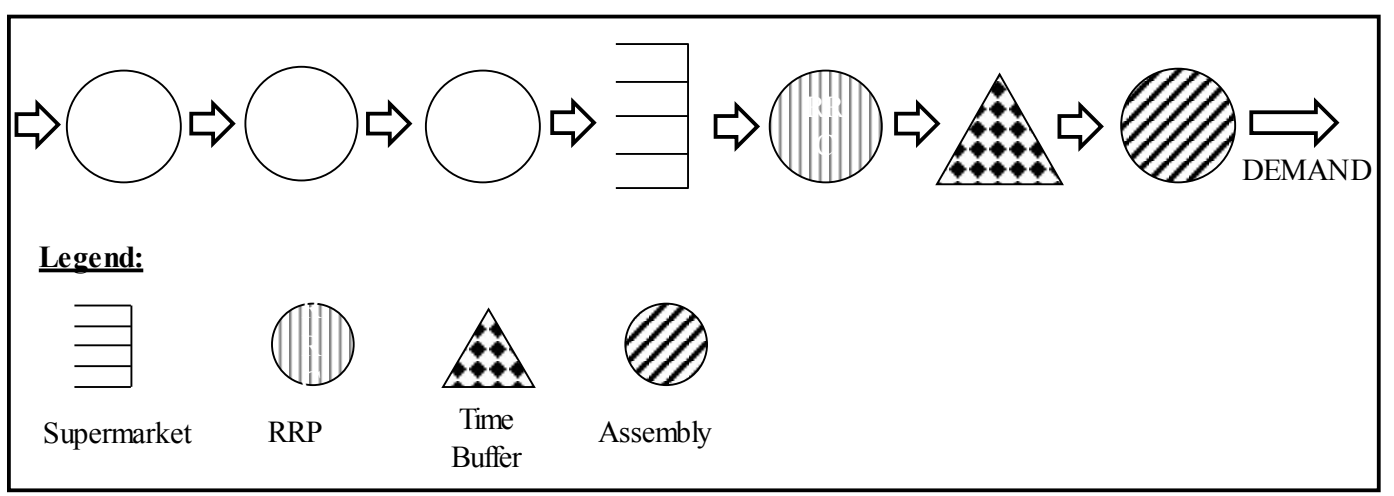


Even though it is a recent PCS, other references to REDUTEX include Hamja et al. (2017) and Serrato (2018), however none of these articles contributes to further developed REDUTEX. Therefore, this system first lacks simulation studies comparing it to other PCS. Secondly, it also lacks empirical studies, as Serrato (2016) is a unique example.

\subsection{Constant Load}

CONstant LOAD (CONLOAD) is a PCS developed by Rose (1999) to overcome the difficulty of other systems, such as CONWIP, to deal with changes in product mix, in the transition period when one item is discontinued and another is introduced (Rose 2001). Such changes are very frequent in the semiconductor industry, where there are a large number of products with a very short life cycle due to technological changes.

CONLOAD was developed merging concepts of CONWIP and Workload Control (Rose 1999). Instead of controlling the WIP (like CONWIP), CONLOAD controls the bottleneck load. The bottleneck load is equal to the processing times in the bottleneck of all orders that already have been released, but have not yet been processed in the bottleneck. Therefore, a job enters the system only if its processing time in the bottleneck plus the processing time in the bottleneck of all orders already released do not exceed a predefined workload (Figure 14).

A constraint of CONLOAD is the necessity to know products' cycle times with high accuracy (Rose 2001). If this cycle time is overestimated, the bottleneck will become idle. If it is underestimated, the bottleneck will be overloaded and there will be accumulation of orders in front of this resource. 
Figure 14. CONLOAD.

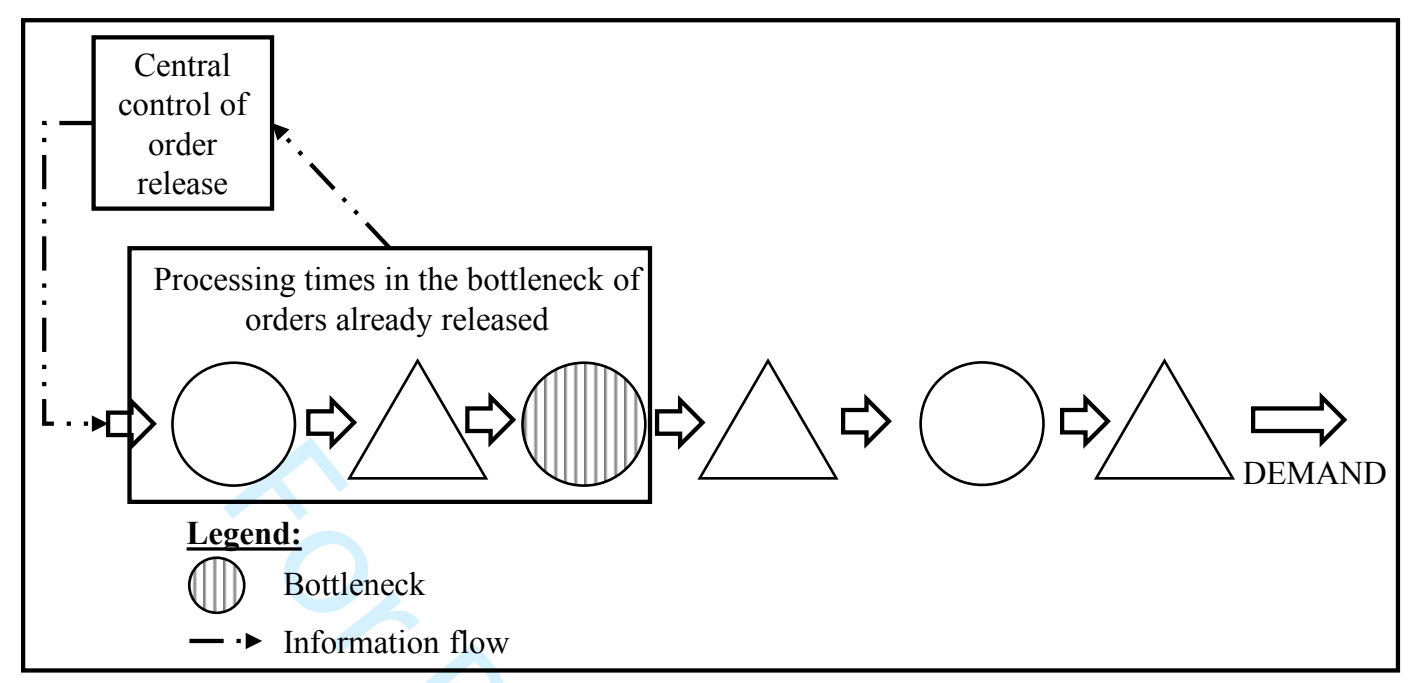

Rose (1999) compared CONLOAD to CONWIP and Workload Regulation and found that CONLOAD is more efficient in maintaining the utilization level of the bottleneck while WIP evolves more smoothly over time.

CONLOAD was little study in literature and, as many other systems of this review, lacks empirical studies.

\subsection{Decentralized Work in Process}

The Decentralized Work in Process (DEWIP) was developed by Lödding and Wiendahl (2000) for job shop environments with the aim of offering smaller and more reliable lead times (Lödding, Yu, and Wiendahl 2003). Although there are many simulation studies about this PCS, no empirical study was found in literature.

The motivation to develop DEWIP arose from the fact that, although there are several decentralized systems whose primary control variable is WIP (Kanban and POLCA, for example), none of them is suitable for environments with complex flow of materials. 
In DEWIP, all orders are programmed by a Central PCP, which sets production priorities. However, the actual moment when each operation starts is controlled by WIP as follows:

- The operator of a work center A checks the first order that needs to be produced and asks for authorization for the next work center (go-ahead request) (Figure $15)$

Figure 15. DEWIP.

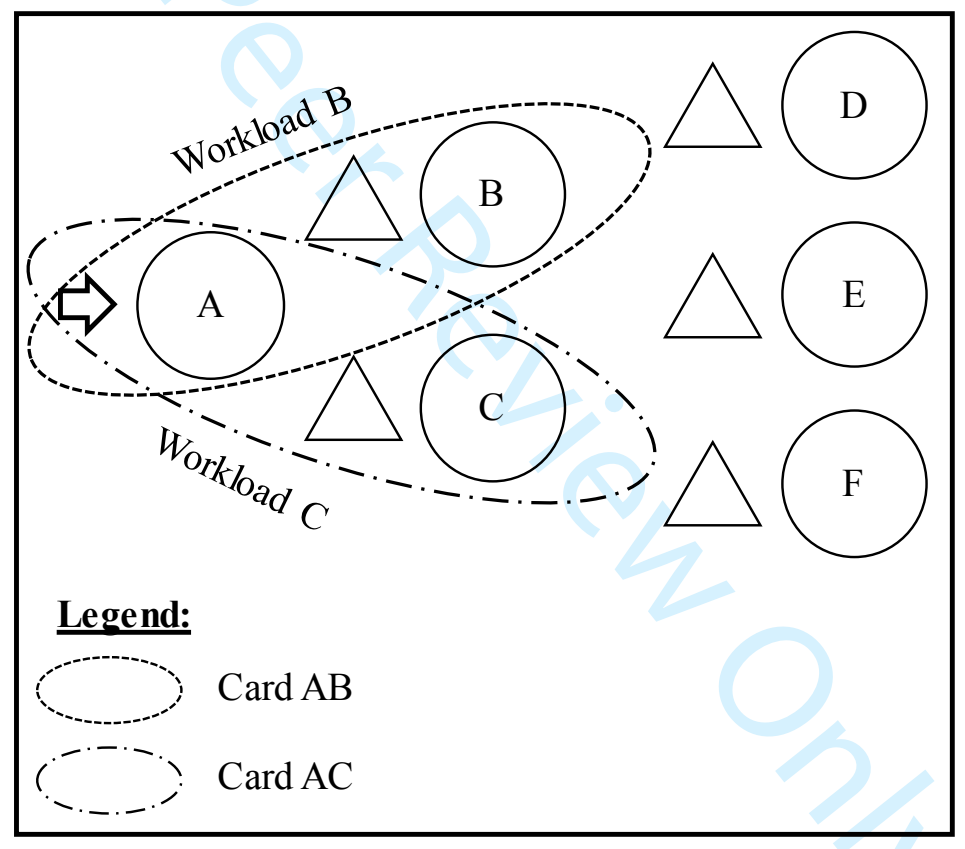

- The downstream work center operator (B) verifies the workload of its own center (direct WIP) as well as the production authorizations already provided to upstream centers (indirect WIP). If releasing the new order, the total WIP (direct + indirect) exceeds a pre-set threshold, authorization is not provided. 
- If authorization is provided, center A starts production and reduces its WIP, providing authorizations for the upstream work centers;

- If authorization is not provided, the operator of center A searches for the next order that is not processed in center B (which is possible because the environment is a job shop) and requests authorization for another center (C).

This evaluation is performed in all work centers, establishing control loops between them. The only exception is critical resources, for which authorizations are always provided.

\section{Discussion of Results: Comparison of New Production Control Systems (PCS)}

Table 2 presents the 13 PCS's identified in the SLR and their classification according to the five variables of system's characteristic's dimensions. Meanwhile, Figure 16 presents the systems evolution using the two variables: number of publications and type (empirical or theoretical).

Regarding the systems evolution dimension, first it can be observed that each system was developed by only one or two groups of authors. These can be one of the reasons why these systems are still little known in practice.

Secondly, it is important to highlight that while some systems were developed almost 20 years ago others are much more recent. Therefore, while B-CONWIP still have a high probability to thrive, chances for IBS are much slower. In our analysis, we could not find any prediction to the success of a PCS's, however it may be due to the systems characteristics itself, to the journal it was published, to the group of authors that proposed the system, among other possibilities. 
Table 2. The 13 PCS's classified according to the five variables of system's characteristics dimension.

\begin{tabular}{|c|c|c|c|c|c|c|c|c|}
\hline System & Acronyms & Year & Main Reference & $\begin{array}{l}\text { Primary } \\
\text { Control } \\
\text { Variable }\end{array}$ & $\begin{array}{c}\text { Level of } \\
\text { Centralization }\end{array}$ & $\begin{array}{c}\text { Applicability } \\
\text { to material } \\
\text { flows }\end{array}$ & $\begin{array}{l}\text { Card- } \\
\text { based }\end{array}$ & $\begin{array}{l}\text { Types of order } \\
\text { authorization }\end{array}$ \\
\hline Inverse Base Stock & IBS & 1999 & Masin (1999) & WIP & Centralized & Flow shop & Yes & 1 \\
\hline CONstant LOAD & CONLOAD & 1999 & Rose (1999) & WIP & Centralized & Flow shop & No & 1 \\
\hline $\begin{array}{c}\text { Customize Token-based } \\
\text { system }\end{array}$ & CTBS & 2000 & $\begin{array}{l}\text { Gaury, Pierreval, } \\
\text { and Kleijnen } \\
(2000)\end{array}$ & WIP & Hybrid & Flow shop & Yes & $\mathrm{n}$ (simultaneos) \\
\hline $\begin{array}{l}\text { Double Speed Single } \\
\text { Production Line }\end{array}$ & DSSPL & 2000 & $\begin{array}{l}\text { Stagno, Glardon, } \\
\text { and Pouly (2000) }\end{array}$ & WIP & Centralized & Flow shop & Partially & 2 \\
\hline $\begin{array}{l}\text { Decentralised Work in } \\
\text { Process }\end{array}$ & DEWIP & 2000 & $\begin{array}{c}\text { Lödding and } \\
\text { Wiendahl }(2000)\end{array}$ & WIP & Decentralized & Job shop & No & 1 \\
\hline $\begin{array}{l}\text { Behaviour Based } \\
\text { Control }\end{array}$ & $\mathrm{BBC}$ & 2001 & $\begin{array}{l}\text { Paternina-Arboleda } \\
\text { and Das (2001) }\end{array}$ & WIP & Hybrid & Flow shop & Yes & 3 (simultaneos) \\
\hline Gated MaxWIP & G-MaxWIP & 2002 & $\begin{array}{l}\text { Grosfeld-Nir and } \\
\text { Magazine (2002) }\end{array}$ & WIP & Centralized & Flow shop & Yes & 1 \\
\hline Parallel Pull Flow & $\mathrm{PPF}$ & 2004 & Hunter et al. (2004) & WIP & Centralized & Flow shop & Yes & 1 \\
\hline $\begin{array}{l}\text { Control of Balance by } \\
\text { Card Based Navigation }\end{array}$ & COBACABANA & 2009 & Land (2009) & WIP & Centralized & Job shop & Yes & 1 \\
\hline $\begin{array}{c}\text { Demand Driven } \\
\text { Materials Requirement } \\
\text { Planning }\end{array}$ & DDMRP & 2011 & $\begin{array}{l}\text { Ptak and Smith } \\
\text { (2011) }\end{array}$ & Throughput & Centralized & Job shop & Partially & 2 \\
\hline $\begin{array}{c}\text { Basestock Kanban- } \\
\text { Constant Work-in- } \\
\text { Process } \\
\end{array}$ & BK-CONWIP & 2012 & $\begin{array}{l}\text { Onyeocha and } \\
\text { Geraghty (2012) }\end{array}$ & WIP & Hybrid & Flow shop & Yes & 3 (simultaneos) \\
\hline REDUTEX & - & 2016 & Serrato (2016) & Throughput & Centralized & Flow shop & Partially & 1 \\
\hline $\begin{array}{l}\text { Basestock-Constant } \\
\text { Work-in- Process }\end{array}$ & B-CONWIP & 2018 & $\begin{array}{l}\text { Hawari, Qasem, } \\
\text { and Smadi (2018) }\end{array}$ & WIP & Centralized & Flow shop & Yes & 2 (simultaneos) \\
\hline
\end{tabular}


Figure 16. Production Control Systems evolution from 1999 to 2018.

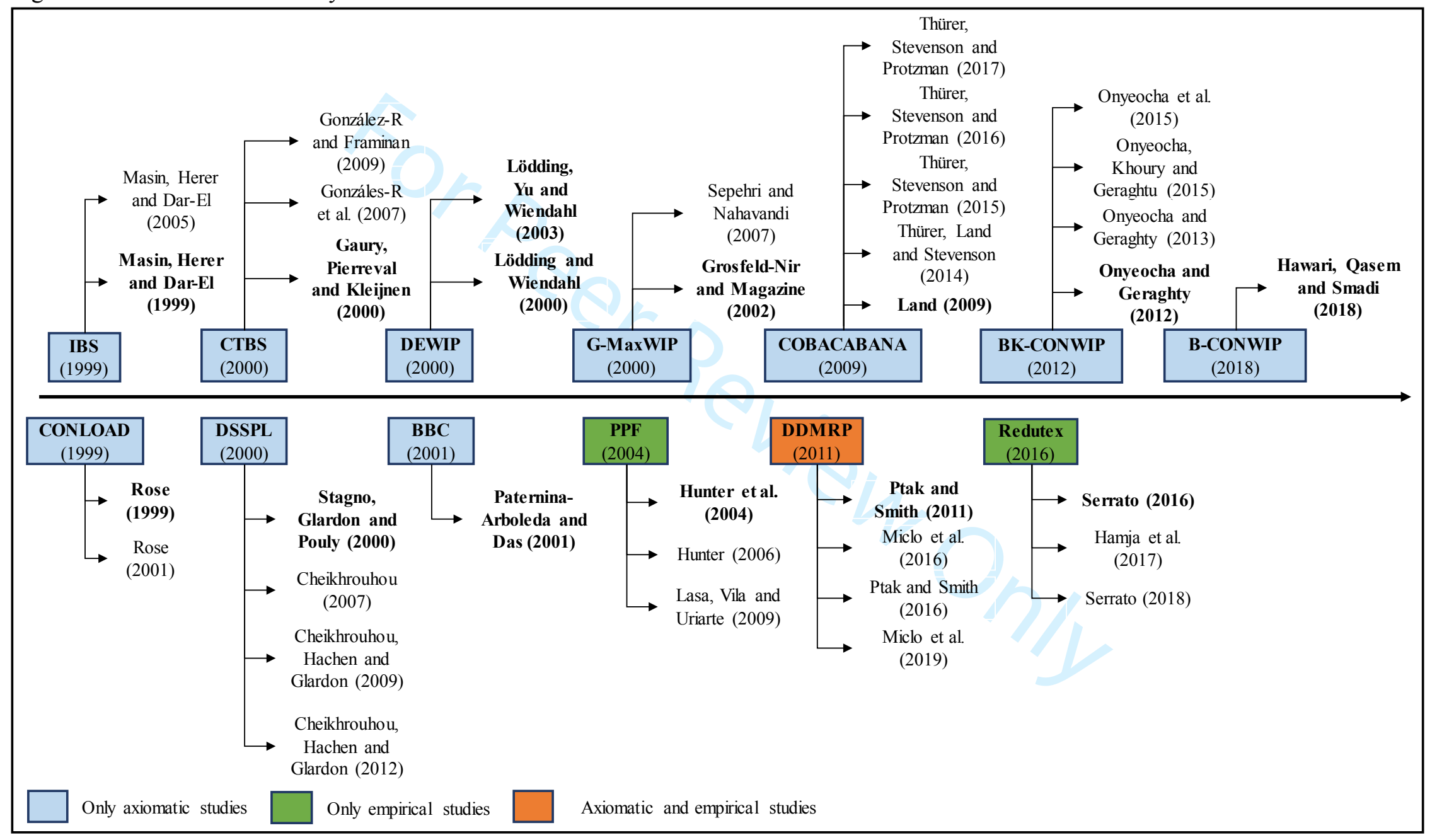


Thirdly, we observed that almost all PCS's have been developed only in theory, specifically by mathematical simulations. PPF, DDMRP and REDUTEX are the only counterexamples, that is, systems that have been developed from practice. This can be explained by the advances in computing, which made simulation faster and able to work with more data, and, therefore, closer to reality. However, this scenario also led to an unwanted effect, that is, many PCS's do not have empirical studies showing their application in practice. Therefore, theory and practice of PCS's may be taken different paths.

Fourthly, we only find theoretical and empirical studies about one of the 13 PCS's (DDMRP). This is a problem even for PPF and REDUTEX, as theoretical studies, such as computer simulation, could help to optimize systems parameters, increasing the chances of an empirical successful implementation of these PCS's. Moreover, it reinforces the idea of theory and practice of PCS's following different paths.

Regarding the system's characteristics dimension, first we noticed predominance of systems (7 out of 13) which present WIP as primary control variable, are designed for flow shop environments and are introduced as card-based systems. Moreover, 5 PCS's have only one type of order authorization. In our understanding this is due to Lean influence, as Kanban and CONWIP, two of the most well-known PCS's, also present these characteristics. DDMRP (not included among the 7 systems because is primary control variable is throughput) also contributes to this view, as it combines MRP principles with Lean. The predominance of systems based on Lean may be a result of the success of this approach in the Western World, especially after its large diffusion by books as "The machine that changed the world" (Roos, Womack, and Jones 1991; 
Bhamu and Sangwan 2014).

Secondly, we observed that the 13 PCS's came from a much more homogeneous manufacturing approach than classical systems. While many of the new systems are based on Lean, classical systems came from a much more heterogeneous set manufacturing concepts, such as Lean (e.g. Kanban, CONWIP), Theory of Constraints (e.g. DBR), Quick Response Manufacturing (e.g. POLCA), Mass Production (e.g. MRP), among others.

Thirdly, among the 13 systems, DEWIP and COBACABANA are different because they are the only ones designed for job shop environments. Curiously, both systems were developed from the Workload Control approach, but in COBACABANA there is also a strong influence of Lean regarding visual control and the role of cards. This is interesting as production shop floor are becoming more and more complex. Therefore, we expected in next years more PCS's for job shop will be proposed.

\section{Conclusions and Research Agenda}

\subsection{Conclusions}

PCS's are a key determinant of the effectiveness of manufacturing systems.

Consequently, many different PCS's emerged and a broad literature on PCS's exists. While many researchers and managers are aware of some major PCS's, more recent advances in the field of PCS's are less known. In response, this study asked: What are the characteristics of Production Control Systems that newly emerged in the last 20 years? Using a systematic literature review, 13 new PCS's could be identified. Their key characteristics, mechanisms and environment in which they are adequate were then discussed. 
Among the PCS, 7 out of the 13 presented WIP as primary control variable, are designed for flow shop environments and were introduced as card-based. Moreover, 5 out of the 7 have only one type of order authorization. Those characteristics are also presented by Kanban and CONWIP, two of the most important PCS's based on Lean approach, which focus on tool's simplicity and on the importance of people, making the system easy to be implemented. Therefore, there is a clear movement to approximate theory and practice, that is, to implement PCS.

However, it was also observed that many new PCS's were developed from simulation studies and lack empirical results, distancing theory from practice. Therefore, two contrary movements are occurring at the same time, making PCS's simpler to be implemented, but lacking studies to test the effective of those systems in practice.

In terms of research, we set out to outline new search directions for future research on PCS's, in special, showing the necessity of more empirical studies about PCS's proposed in the latest 20 years. In terms of practice, we hope that our study helps engineers and managers to find new solutions to their day-to-day problems, knowing a larger number of PCS's, and to apply systems more adherent to their productive environment, increasing the probability of success of PCS's implementation.

A major limitation of our study is that we not discuss in depth each PCS's. However, we preferred to include all the 13 PCS's identified in the SLR in order to show all the possibilities available instead of choosing only some of those systems. In the research agenda, we proposed more studies about each PCS's regarding implementation, applicability, comparison among systems, among others. Moreover, our study only identified articles written in English, so PCS's proposed in other languages were not included in this paper and could be added in future studies. 


\subsection{Research Agenda}

Due to the limited body of existing research about new PCS's and following

Table 3. Research gaps and future research directions.

\begin{tabular}{|c|c|c|}
\hline Subject & Motivation & Potential research questions \\
\hline \multicolumn{3}{|c|}{ Understanding the new PCS's } \\
\hline $\begin{array}{l}\text { Implementation } \\
\text { of PCS's }\end{array}$ & $\begin{array}{l}\text { For the majority of the PCS's } \\
\text { presented in this paper, there } \\
\text { is no empirical study } \\
\text { reporting the implementation } \\
\text { of one of the } 13 \text { PCS. }\end{array}$ & $\begin{array}{c}\text { For each of the } 13 \text { PCS's: } \\
\text { What are the difficulties to } \\
\text { implement the system? } \\
\text { Does the system need any } \\
\text { adaptation to be implemented? } \\
\text { Does the system achieve the } \\
\text { expected results of simulation } \\
\text { studies? }\end{array}$ \\
\hline $\begin{array}{l}\text { Applicability } \\
\text { of PCS's }\end{array}$ & $\begin{array}{l}\text { As there is a lack of papers } \\
\text { about recent PCS's, it is } \\
\text { important to verify their } \\
\text { suitability in different } \\
\text { environments in order to } \\
\text { increase their chance of } \\
\text { success in empirical } \\
\text { implementations. }\end{array}$ & $\begin{array}{l}\text { Which environment are adequate to } \\
\text { each system? } \\
\text { Which environment are not? } \\
\text { How each system can be adapted to } \\
\text { be suitable for an environment } \\
\text { different of its initial proposal? }\end{array}$ \\
\hline Comparison & $\begin{array}{l}\text { Comparison studies of new } \\
\text { PCS's are limited to some } \\
\text { systems, such as Kanban, } \\
\text { BK-CONWIP and B- } \\
\text { CONWIP. It is essential to } \\
\text { compare them in order to } \\
\text { understand their performance } \\
\text { differences in some key } \\
\text { indicators, such as stock } \\
\text { levels and throughput rates. }\end{array}$ & $\begin{array}{l}\text { For a given environment: } \\
\text { Which PCS's (new or classical) is } \\
\text { better to control WIP? And } \\
\text { throughput? And a combination of } \\
\text { both metrics? }\end{array}$ \\
\hline
\end{tabular}


PCS's in complex environments

\begin{tabular}{|c|c|c|}
\hline \multicolumn{3}{|c|}{ PCS's in complex environments } \\
\hline Collaboration & $\begin{array}{l}\text { As production shop floors } \\
\text { become more complex, it is } \\
\text { necessary to understand how } \\
\text { PCS's can be combined in } \\
\text { order managers could choose } \\
\text { solutions more adherent to } \\
\text { their environment. }\end{array}$ & $\begin{array}{l}\text { How new and old systems can be } \\
\text { combined horizontally (different } \\
\text { production stages) and vertically } \\
\text { (in different levels of the } \\
\text { hierarchical production planning)? }\end{array}$ \\
\hline $\begin{array}{l}\text { PCS in Supply } \\
\text { Chain }\end{array}$ & $\begin{array}{l}\text { As competitions against } \\
\text { supply chains, instead of } \\
\text { single organizations, are } \\
\text { becoming more usual, it is } \\
\text { important to studied PCS's is } \\
\text { this wider environment. }\end{array}$ & $\begin{array}{l}\text { How can a PCS be applied to whole } \\
\text { supply chains? } \\
\text { How companies shared information } \\
\text { among themselves to take shop } \\
\text { floor decisions? }\end{array}$ \\
\hline \multicolumn{3}{|c|}{$\begin{array}{r}\text { Environmental forces } \\
\end{array}$} \\
\hline $\begin{array}{l}\text { Technology } \\
\text { and Industry } \\
4.0\end{array}$ & $\begin{array}{l}\text { Technology development can } \\
\text { affect greatly actual PCS's as } \\
\text { well as the proposal of new } \\
\text { ones. For example, big data } \\
\text { and analytics can become } \\
\text { extremely complex } \\
\text { centralized PCS's, while } \\
\text { internet of machines can push } \\
\text { new systems to a } \\
\text { decentralized direction. }\end{array}$ & $\begin{array}{l}\text { How the use of technologies, } \\
\text { especially the ones emerging with } \\
\text { Industry 4.0, can affect the } \\
\text { development and choice of PCS's? } \\
\text { How can artificial intelligence, } \\
\text { internet of things and machine } \\
\text { learning become feasible } \\
\text { decentralized systems on which } \\
\text { each machine could take decisions } \\
\text { based on the past experiences and } \\
\text { communicate one with the other? }\end{array}$ \\
\hline Sustainability & $\begin{array}{l}\text { Questions such as carbon } \\
\text { emission, reduction of waste } \\
\text { and energy economy, among } \\
\text { others, can lead to different } \\
\text { objectives of PCS's in the } \\
\text { next years, because } \\
\text { traditional ones do not focus } \\
\text { on these questions. For } \\
\text { example, a PCS focus on } \\
\text { reducing carbon emission } \\
\text { may neither control } \\
\text { throughput rates nor WIP, but } \\
\text { a third metric. This could lead } \\
\text { to a new group of PCS, } \\
\text { focusing on optimizing } \\
\text { sustainability objectives. }\end{array}$ & $\begin{array}{l}\text { How efficient is each PCS to deal } \\
\text { with carbon emission metric? And } \\
\text { with energy economy? } \\
\text { How can a new PCS be developed } \\
\text { seeking to optimize carbon } \\
\text { emission? } \\
\text { How can }\end{array}$ \\
\hline
\end{tabular}




\begin{tabular}{|c|c|c|}
\hline $\begin{array}{l}\text { Circular } \\
\text { Economy }\end{array}$ & $\begin{array}{l}\text { The objective to maximize } \\
\text { the circularities of products } \\
\text { can also affect the choice and } \\
\text { development of new PCS. }\end{array}$ & $\begin{array}{l}\text { How can real time communication } \\
\text { between market conditions and the } \\
\text { machine themselves predict better } \\
\text { deliver times to clients, optimize } \\
\text { set ups, increase efficiency, reduce } \\
\text { stocks and revise expected lead } \\
\text { times based on the shop-floor } \\
\text { scenario? } \\
\text { How PCS's will deal with } \\
\text { remanufacturing, as it increases the } \\
\text { number of materials entry points on } \\
\text { shop floor as well as production } \\
\text { routings? }\end{array}$ \\
\hline \multicolumn{3}{|c|}{ Proposal of new PCS's } \\
\hline $\begin{array}{c}\text { Characteristics } \\
\text { of new PCS }\end{array}$ & $\begin{array}{l}\text { As identified the } \\
\text { characteristics of PCS's } \\
\text { developed over the last } 20 \\
\text { years, it is interesting to } \\
\text { evaluate how actual forces } \\
\text { will influence the proposal of } \\
\text { new PCS's in the next years. }\end{array}$ & $\begin{array}{l}\text { What will be the characteristics of } \\
\text { PCS's in the next } 10 \text { or } 20 \text { years? } \\
\text { Will they still be based on Lean or } \\
\text { another approach will become } \\
\text { predominant? } \\
\text { How systems will deal with the } \\
\text { increasing complexity on } \\
\text { production environments? }\end{array}$ \\
\hline
\end{tabular}

\section{References}

Bahmu, J., and K.S. Sangwan. 2014. "Lean manufacturing: literature review and research issues." International Journal of Production \& Operations Management 34 (7): 876-940. doi: org/10.1108/IJOPM-08-2012-0315.

Baynat, B., J.A. Buzacott, and Y. 2002. "Multiproduct Kanban-like control systems." International Journal of Production Research 40 (16) 4225-4255. doi: org/10.1080/00207540210146198.

Benders, J., and J. Riezebous, J. 2002. "Period Batch Control: classic, not outdated." Production Planning and Control 13 (6): 497-506. doi: org/10.1080/09537280210162941.

Berkley, B.J. 1992. "A review of the kanban production control research literature." Production and Operations Management 1 (4): 393-411. doi: org/10.1111/j.19375956.1992.tb00004.x.

Bertrand, J.W.M., Fransoo, J.C. 2002. "Modelling and simulations: operations management research methodologies using quantitative modeling." International Journal of Operations \& Production Management 22 (2): 241-264. doi: org/10.1108/01443570210414338.

Bonvik, A.M., C.E. Couch, and S.B. Gershwin 1997. "A comparison of production line control mechanisms." International Journal of Production Research 35: 789-804. doi: org/10.1080/002075497195713.

Burbidge, J. L. 1996. Period batch control. Oxford: Clarendon Press.

Chadegani, A. A., H. Salehi, M.M. Yunus, H. Farhadi, M. Fooladi, M. Farhadi, and N.A. Ebrahim. 2013. "A Comparison between Two Main Academic Literature Collections: 
Web of Science and Scopus Databases." Asian Social Science 9 (5): 18-26. doi: 10.5539/ass.v9n5p18.

Cheikhrouhou, N. 2012. "A multi-criteria decision making approach for the comparison of hybrid production planning and control strategies for supply chain management." 7th International Congress on Logistics and SCM Systems, Seoul.

Cheikhrouhou, N., C. Hachen, and R. Glardon. 2009. "A Markovian model for the hybrid manufacturing planning and control method 'Double Speed Single Production Line"." Computers \& Industrial Engineering 57 (3): 1022-1032. doi: org/10.1016/j.cie.2009.04.013.

Denyer, D. and D. Tranfield D. 2009. Producing a Systematic Review. In The Sage Handbook of Organizational Research Methods, edited by D. Buchanan and A. Bryman, 671-689. London: Sage.

Fawcett, S.E.; M.A. Waller, J.W. Miller, M.A. Schwieterman, B.T. Hazen, and R.E. Overstreet 2014. "A trail guide to publishing Success: Tips on Writing Influential Conceptual, Qualitative, and Survey Research.” Journal of Business Logistics 35 (1): 116. doi: org/10.1111/jbl.12039.

Fernandes, F.C.F. and M. Godinho Filho, M. 2011. "Production control systems: Literature review, classification, and insights regarding practical application." African Journal of business Management 5 (4): 5573-5582. doi: 10.5897/AJBM11.184.

Framinan, J. M., and P.L. Gonzalez and R. Ruiz-Usano. 2003. "The CONWIP production control system: Review and research issues." Production Planning and Control 14: 255265. doi: org/10.1080/0953728031000102595.

Gaury, E.G.A., H. Pierreval, and J.P.C. 2000. "An evolutionary approach to select a pull system among Kanban, Conwip and Hybrid." Journal of Intelligent Manufacturing 11: 157-167. doi: org/10.1023/A:1008938816257.

Geraghty, J. and C. Heavey, C. 2004. "A comparison of hybrid push/pull and CONWIP/pull production inventory control policies." International Journal of Production Economics 91: 75-90. doi: org/10.1016/S0925-5273(03)00210-X.

Goldratt, W. M. 1990. What is this thing called the theory of constraints? New York: The North River Press.

Gong, D.C., C.W. Kao and B.A. Peters. 2019. "Sustainability investments and production planning decisions based on environmental management." Journal of Clearer Production 225: 196-208. doi: org/10.1016/j.jclepro.2019.03.256.

González-R., P.L. and J.M. Framinan. 2009. "The pull evolution: from Kanban to customized token-based systems." Production Planning and Control 20 (3): 276-287. doi: org/10.1080/09537280902875393.

González-R., P.L., J.M. Framinan, A. Dopfer and R. Ruiz-Usano. 2007. “Optimization Customized Token-Based Production Control Systems Using Cross-Entropy.” In: Cunha P.F., Maropoulos P.G. (eds) Digital Enterprise Technology. Boston: Springer.

Grosfeld-Nir, A. and M. Magazine. 2002. "Gated MaxWIP: A strategy for controlling multistage production systems." International Journal of Production Research 40 (11): 2557-2567. doi: org/10.1080/00207540210128251.

Guide, V.D.R. 1996. "Scheduling using drum-buffer-rope in remanufacturing environment." International Journal of Production Research 34 (4): 1081-1091. doi: 
org/10.1080/00207549608904951.

Hamja, A., A. Hossain, M.M. Maalouf and P. Hasle. 2017. "A review paper on Lean and Occupational Health and Safety (OHS) in RMG industry." Paper presented at International Conference on Mechanical Engineering and Renewable Energy 2017, Chittagong, Bangladesh, 2017.

Hassan, K. and H. Kajiwara. 2013. "Application of Pull Concept-based Lean Production System in the Ship Building Industry." Journal of Ship Production and Design 29 (3): 105-116. doi: org/10.5957/JSPD.29.3.120021.

Hawari, T.A., A.G. Qasem and H. Smadi. 2018. "Development and evaluation of a Basestock-CONWIP pull production control strategy in balanced assembly systems." Simulation Modelling Practice and Theory 84: 83-105. doi: org/10.1016/j.simpat.2018.01.008.

Hopp, W.J. and M.L. 2008. Spearman. Factory physics: foundation of manufacturing management. New York: McGrawHill/Irwin.

Hunter, S.L. 2006. "Lean production design: Parallel pull flow.” International Journal of Industrial Engineering 13 (3): 254-259.

Hunter, S.L., S.H. Bullard, P.H. Steele and W.D. Motsenbocker. 2004. "Parallel pull flow: A new lean production design." Faculty Publications, Paper 40.

Jabbour, A.B.L.S., C.J.C. Jabbour, M. Godinho Filho and D. Rouband. 2018. "Industry 4.0 and the circular economy: a proposed research agenda and original roadmap for sustainable operations." Annals of Operations Research v. 270 (1-2): 273-286. doi: org/10.1007/s10479-018-2772-8.

Jaegler, Y., A. Jaegler, P. Burlat, S. Lamouru and D. Trentesaux. 2017. "The ConWip production control system: a systematic review and classification." International Journal of Production Research. doi: org/10.1080/00207543.2017.1380325.

Johnson, L. A. and D.C. Montgomery. 1974. Operations Research in Production Planning, Scheduling and Inventory Control. New York: Wiley.

Kaelbling, L.P., M.L. Littman and A.W. Moore. 1996. "Reinforcement learning: a survey." Journal of Artificial Intelligence Research 4: 237-285. doi: org/10.1613/jair.301.

Karrer, C., K. Alicke, and H.-O Günther. 2012. "A framework to engineer production control strategies and its application in electronics manufacturing." International Journal of Production Research 50 (22): 6595-6611. doi: org/10.1080/00207543.2012.658479.

Koulouriotis, D.E., A.S. Xanthopoulos and V.D. Tourassis. 2010. "Simulation optimization of pull control policies for serial manufacturing systems using genetic algorithms." International Journal of Production Research 48 (10): 2887-2912. doi: org/10.1080/00207540802603759.

Lage Junior, M. and M. Godinho Filho, M. 2010. "Variations of the Kanban System: Literature Review and Classification." International Journal of Production Economics 125 (1): 13-21. doi: org/10.1016/j.ijpe.2010.01.009.

Land, M. J. 2006. "Parameters and sensitivity in workload control.” International Journal of Production Economics 104 (2): 625-638. doi: org/10.1016/j.ijpe.2005.03.001.

Land, M. J. 2009. "Cobacabana (control of balance by card-based navigation): A cardbased system for job shop control." International Journal of Production Economics 117 (1): 97-103. doi: org/10.1016/j.ijpe.2008.08.057. 
Land, M. J. and G.J.C. Gaalman. 1998. "The performance of workload control concepts in job shops: Improving the release method." International Journal of Production Economics 56-57: 347-364. doi: org/10.1016/S0925-5273(98)00052-8.

Lasa, I.S., R.C. Villa and A.G. Uriarte. 2009. "Pacemaker, bottleneck and order decoupling point in lean production systems." International Journal of Industrial Engineering 16 (4): 293-304.

Liberopulos, G. and Y. Dallery. 2000. "A unified framework for pull control mechanisms in multi-stage manufacturing systems." Annals of Operations Research 93: 325-355. doi: org/10.1023/A:1018980024795.

Liu, Q. and D. Huang. 2009. "Dynamic card number adjusting strategy in card-based production system." International Journal of Production Research 47 (21): 6037-6050. doi: org/10.1080/00207540802192134.

Lödding, H. and H.P. Wiendahl. 2000. "Decentralized WIP-oriented manufacturing control (DEWIP): A systematic approach to shop floor control." 33rd CIRP International Seminar on Manufacturing System 170-175.

Lödding, H., K. Yu and. H.P Wiendahl. 2003. "Decentralized WIP-oriented manufacturing control (DEWIP)". Production Planning and Control 14 (1): 42-54. doi: org/10.1080/0953728021000078701.

Mabin, V.J. and S.J. Balderstone. 2003. "The performance of the theory of constraints methodology: analysis and discussion of successful TOC applications." International Journal of Operations and Production Management 23: 568-595. doi: org/10.1108/01443570310476636.

Masin, M., Y.T. Herer and E.M. Dar-El. 2005. "Design of self-regulating production control systems by Tradeoffs Programming." IIE Transactions 37 (3): 217-232. doi: org/10.1080/07408170590899616.

Masin, M.; Y.T. Herer and E.M. Dar-El. 1999. "SWIP: a unified model of self-regulating production control systems". Working paper, Tel Aviv University, Tel Aviv, Israel.

Miclo, R., F. Fontanili, M. Lauras, J. Lamothe, and B. Milian. 2016 "An empirical comparison of MRPII and Demand-Driven MRP." IFAC-PapersOnLine 49 (125): 17251730. doi: org/10.1016/j.ifacol.2016.07.831.

Miclo, R., M. Lauras, F. Fontanili, J. Lamothe and S.A. Melnyk. 2019. "Demand Driven MRP: assessment of a new approach to materials management." International Journal of Production Research. doi: org/10.1080/00207543.2018.1464230.

Mohebbi, E., F. Choobineh, F. and A. Pattanayak. 2007. "Capacity-driven vs demanddriven material procurement system." International Journal of Production Economics 107: 451-466. doi: org/10.1016/j.ijpe.2006.09.015.

Monden, Y. 1998. Toyota production system: An integrated approach to just-in-time. Norcross: Engineering \& Management Press.

Negrão, L.L.L., M. Godinho Filho and G. Marodin. 2017. "Lean practices and their effect on performance: a literature review." Production Planning and Control. doi: org/10.1080/09537287.2016.1231853.

Olaitan, O.A. and J. Geraghty, J. 2013. "Evaluation of production control strategies for negligible-setup, multiproduct, serial lines with consideration for robustness." Journal of Manufacturing Technology Management 24 (3): 331-357. doi: 
org/10.1108/17410381311318864.

Olaitan, O.A. and J. Geraghty, J. 2012. "A modification of the Hybrid Kanban-Conwip Production Control Strategy for Multi-Product Manufacturing Systems. " Proceedings of the winter simulation conference, IEEE, 2730-2741.

Onyeocha, C. E., J. Khoury and J. Geraghty. 2015. "Evaluation of multi-product lean manufacturing systems with set up and erratic demand." Computer and Industry Engineering 87: 465-480. doi: org/10.1016/j.cie.2015.05.029.

Onyeocha, C. E., J. Wang, J. Khoury and J. Geraghty. 2015. "A comparison of HKCONWIP and BK-CONWIP control strategies in a multi-product manufacturing system." Operations Research Perspectives. doi: org/10.1016/j.orp.2015.07.001.

Orlicky, J. 1975. Material Requirements Planning. New York: McGraw-Hill.

Paternina-Arboleda, C.D. and T.K. Das. 2001. "Intelligent dynamic control policies for serial production lines." IIE Transactions 33 (1): 65-77. org/10.1080/07408170108936807

Prakash, J. and J.F. Chin. 2014. "Modified CONWIP systems: a review and classification." Production Planning and Control 26 (4): 296-307. org/10.1080/09537287.2014.898345

Ptak, C. and C, Smiith. 2016. Demand Driven Material Requirements Planning $(D D M R P)$. New York: Industrial Press.

Ptak, C. and C, Smiith. 2011. Orlicky's Material Requirements Planning. New York: McGraw Hill Professional.

Riezebos, J. 2010. "Design of POLCA material control systems." International Journal of Production Research 48 (5): 1455-1477. doi: org/10.1080/00207540802570677.

Roos, D., J. Womack and D.T. Jones, 1991. The Machine That Changed the World: The Story of Lean Production. New York: Harper Perennial.

Rose, O. 1999. "CONLOAD - A New Lot Release Rule for Semiconductor Wafer Fabs." In: Proceedings of the 1999 Winter Simulation Conference, Phoenix.

Rose, O. 2001. "CONWIP-like Lot Release for a Wafer Fabrication Facility with Dynamic Load Changes." In: Proceedings of the 2001 International Conference on Semiconductor Operational Modeling and Simulation, Seattle.

Sato, R. and Y. Khojasteh-Ghamari. 2012. "An integrated framework for card-based production control systems." Journal of Intelligent Manufacturing 23 (3): 717-731. doi: org/10.1007/s10845-010-0421-4.

Sepehri, M.M. and N. Nahavandi. 2007. "Critical WIP loops: a mechanism for material flow control in flow lines." International Journal of Production Research 45 (12): 27592773. doi: org/10.1080/00207540600787077.

Serrato, R. B. 2016. "REDUTEX: a hybrid push-pull production system approach for reliable delivery time in knitting SMEs." Production Planning and Control 27 (4): 263279. doi: org/10.1080/09537287.2015.1120362.

Serrato, R.B. 2018. "Stochastic plans in SMEs: A novel multidimensional fuzzy logic system (mFLS) approach." Ingeniería e Investigacion 38 (2): 70-78. doi: org/10.15446/ing.investig.v38n2.6535.

Silva, C., V. Reis, A. Morais, I. Brilenkov, J. Vaza, T. Pinheiro, and M. Neves et al. 2017. 
"A comparison of production control systems in a flexible flow shop." Procedia Manufacturing 13: 1090 - 1095. doi: org/10.1016/j.promfg.2017.09.169.

Spearman, M.L., D.L. Woodruff, and W.J. Hopp. 1990. "CONWIP: a pull alternative to Kanban." International Journal of Production Research 28 (5): 879-894. doi: org/10.1080/00207549008942761.

Stagno, A., R. Glardon, and M. Pouly. 2000. "Double speed single production line." Journal of Intelligent Manufacturing 11: 169-182. doi: org/10.1023/A:1008990800328.

Stevenson, M., L.C. Hendry, and B.G. Kingsman. 2005. "A review of production planning and control: the applicability of key concepts to the make-to-order industry." International Journal of Production Research 53 (5): 869-898. doi: org/10.1080/0020754042000298520.

Sugimori, Y., K. Kusunoki, F. Cho, and S. Uchikawa. 1977. "Toyota production system and Kanban system Materialization of just-in-time and respect-for-human system." International Journal of Production Research 15 (6): 553-564.

Siru, R. 1998. Quick Response Manufacturing. Portland: Productivity Press.

Teng, G., and H. Jaramillo. 2006. "Integrating the US Textile and Apparel Supply Chain with Small Companies in South America." Supply Chain Management: An International Journal 11 (1): 44-55. doi: org/10.1108/13598540610642466.

Thomé, A. M. T., R.L. Hollmann, and L.F. Scavarda. 2014. "Research Synthesis in Collaborative Planning Forecast and Replenishment." Industrial Management and Data Systems 111 (6): 949-965. doi: org/10.1108/IMDS-03-2014-0085.

Thürer, M., N.O. Fernandes, M. Stevenson, T. Qu, and C.D. Li. 2019. "Centralised vs. decentralised control decision in card-based control systems: comparing kanban systems and COBACABANA". International Journal of Production Research. doi: org/10.1080/00207543.2018.1425018.

Thürer, M., M.J. Land, and M. Stevenson. 2014. "Card-based workload control for job shops: Improving COBACABANA." International Journal of Production Economics 147: 180-188. doi: doi.org/10.1080/00207543.2011.631600.

Thürer, M., M. Stevenson, M., and C.W. Protzman. 2017. "Card-based production control: a review of the control mechanisms underpinning Kanban, ConWIP, POLCA and COBACABANA systems." Production Planning and Control 27 (14): 1143-1157 . doi: 10.1080/09537287.2016.1188224.

Thürer, M., M. Stevenson, M., and C.W. Protzman. 2015. "COBACABANA (Control of Balance by Card Based Navigation): An alternative to kanban in the pure flow shop?" International Journal of Production Economics 166: 143-151. doi 10.1016/j.ijpe.2015.05.010.

Tranfield, D., D. Denyer, and P. Smart. 2003. "Towards a Methodology for Developing Evidence-Informed Management Knowledge by Means of Systematic Review." British Journal of Management 14: 207-222. doi: org/10.1111/1467-8551.00375.

Wang, Y., J. Cao, J., and L. Kog. 2009. "Hybrid Kanban/CONWIP control system simulation and optimization based on theory of constraints." Conference Proceedings on Intelligent Computing and Intelligent Systems, IEEE International Conference, Shanghai, 2: 666-670. doi: 10.1109/ICICISYS.2009.5358303.

Zheng, P., H. Wang, Z. Sang, R.Y. Zhong, Y. Liu, C. Liu, K. Mubarok, S. Yu, and X. 
Xu. 2018. "Smart manufacturing systems for Industry 4.0: Conceptual framework, scenarios, and future perspectives." Frontiers of Mechanical Engineering 13 (2): 137150. doi: org/10.1007/s11465-018-0499-5.

Zhong, R.Y., X. Xu, E. Klotz, and S.T. Newman. 2017. "Intelligent Manufacturing in the Context of Industry 4.0: A Review." Engineering 3 (5): 616-630. doi: org/10.1016/J.ENG.2017.05.015. 
Table 1. Research Protocol.

\begin{tabular}{ll}
\hline & \multicolumn{1}{c}{ Research Protocol } \\
\hline & Web of Science, Scopus, Google Scholar, Emerald Cite and \\
Database & Engineering Village \\
Publication Years & From 1999 to 2018 \\
Document type & Journals \\
Language & English \\
Strings & "production control system*" \\
& "production system" AND "push*" \\
& "production system*" AND "pull" \\
& "card based" AND "production" \\
& "production system" AND "hybrid" \\
& "production control" AND "pull" \\
& "production control" AND "push*" \\
& - Articles featuring a new PCS \\
Inclusion criteria & - Applications or comparisons of PCS's developed over \\
& the last 20 years \\
- Evolution of classical systems, such as Kanban and & CONWIP; \\
Exclusion criteria & - Application of sequencing rules to prioritize production; \\
& - Review literature of existing PCS \\
\hline
\end{tabular}


Table 2. The 13 PCS's classified according to the five variables of system's characteristics dimension.

\begin{tabular}{|c|c|c|c|c|c|c|c|c|}
\hline System & Acronyms & Year & Main Reference & $\begin{array}{l}\text { Primary } \\
\text { Control } \\
\text { Variable } \\
\end{array}$ & $\begin{array}{c}\text { Level of } \\
\text { Centralization }\end{array}$ & $\begin{array}{c}\text { Applicability } \\
\text { to material } \\
\text { flows }\end{array}$ & $\begin{array}{l}\text { Card- } \\
\text { based }\end{array}$ & $\begin{array}{l}\text { Types of order } \\
\text { authorization }\end{array}$ \\
\hline Inverse Base Stock & IBS & 1999 & Masin (1999) & WIP & Centralized & Flow shop & Yes & 1 \\
\hline CONstant LOAD & CONLOAD & 1999 & Rose (1999) & WIP & Centralized & Flow shop & No & 1 \\
\hline $\begin{array}{l}\text { Customize Token-based } \\
\text { system }\end{array}$ & CTBS & 2000 & $\begin{array}{l}\text { Gaury, Pierreval, } \\
\text { and Kleijnen } \\
(2000)\end{array}$ & WIP & Hybrid & Flow shop & Yes & n (simultaneos) \\
\hline $\begin{array}{l}\text { Double Speed Single } \\
\text { Production Line }\end{array}$ & DSSPL & 2000 & $\begin{array}{l}\text { Stagno, Glardon, } \\
\text { and Pouly (2000) }\end{array}$ & WIP & Centralized & Flow shop & Partially & 2 \\
\hline $\begin{array}{c}\text { Decentralised Work in } \\
\text { Process }\end{array}$ & DEWIP & 2000 & $\begin{array}{c}\text { Lödding and } \\
\text { Wiendahl (2000) }\end{array}$ & WIP & Decentralized & Job shop & No & 1 \\
\hline $\begin{array}{c}\text { Behaviour Based } \\
\text { Control }\end{array}$ & $\mathrm{BBC}$ & 2001 & $\begin{array}{c}\text { Paternina-Arboleda } \\
\text { and Das (2001) }\end{array}$ & WIP & Hybrid & Flow shop & Yes & 3 (simultaneos) \\
\hline Gated MaxWIP & G-MaxWIP & 2002 & $\begin{array}{l}\text { Grosfeld-Nir and } \\
\text { Magazine (2002) }\end{array}$ & WIP & Centralized & Flow shop & Yes & 1 \\
\hline Parallel Pull Flow & PPF & 2004 & Hunter et al. (2004) & WIP & Centralized & Flow shop & Yes & 1 \\
\hline $\begin{array}{l}\text { Control of Balance by } \\
\text { Card Based Navigation }\end{array}$ & COBACABANA & 2009 & Land (2009) & WIP & Centralized & Job shop & Yes & 1 \\
\hline $\begin{array}{c}\text { Demand Driven } \\
\text { Materials Requirement } \\
\text { Planning }\end{array}$ & DDMRP & 2011 & $\begin{array}{l}\text { Ptak and Smith } \\
\qquad(2011)\end{array}$ & Throughput & Centralized & Job shop & Partially & 2 \\
\hline $\begin{array}{c}\text { Basestock Kanban- } \\
\text { Constant Work-in- } \\
\text { Process }\end{array}$ & BK-CONWIP & 2012 & $\begin{array}{c}\text { Onyeocha and } \\
\text { Geraghty (2012) }\end{array}$ & WIP & Hybrid & Flow shop & Yes & 3 (simultaneos) \\
\hline REDUTEX & - & 2016 & Serrato (2016) & Throughput & Centralized & Flow shop & Partially & 1 \\
\hline $\begin{array}{c}\text { Basestock-Constant } \\
\text { Work-in- Process }\end{array}$ & B-CONWIP & 2018 & $\begin{array}{l}\text { Hawari, Qasem, } \\
\text { and Smadi (2018) }\end{array}$ & WIP & Centralized & Flow shop & Yes & 2 (simultaneos) \\
\hline
\end{tabular}


Table 3. Research gaps and future research directions.

\begin{tabular}{|c|c|c|}
\hline Subject & Motivation & Potential research questions \\
\hline \multicolumn{3}{|c|}{ Understanding the new PCS's } \\
\hline $\begin{array}{l}\text { Implementation } \\
\text { of PCS's }\end{array}$ & $\begin{array}{l}\text { For the majority of the PCS's } \\
\text { presented in this paper, there } \\
\text { is no empirical study } \\
\text { reporting the implementation } \\
\text { of one of the } 13 \text { PCS. }\end{array}$ & $\begin{array}{c}\text { For each of the } 13 \text { PCS's: } \\
\text { What are the difficulties to } \\
\text { implement the system? } \\
\text { Does the system need any } \\
\text { adaptation to be implemented? } \\
\text { Does the system achieve the } \\
\text { expected results of simulation } \\
\text { studies? }\end{array}$ \\
\hline $\begin{array}{c}\text { Applicability } \\
\text { of PCS's }\end{array}$ & $\begin{array}{l}\text { As there is a lack of papers } \\
\text { about recent PCS's, it is } \\
\text { important to verify their } \\
\text { suitability in different } \\
\text { environments in order to } \\
\text { increase their chance of } \\
\text { success in empirical } \\
\text { implementations. }\end{array}$ & $\begin{array}{l}\text { Which environment are adequate to } \\
\text { each system? } \\
\text { Which environment are not? } \\
\text { How each system can be adapted to } \\
\text { be suitable for an environment } \\
\text { different of its initial proposal? }\end{array}$ \\
\hline Comparison & $\begin{array}{l}\text { Comparison studies of new } \\
\text { PCS's are limited to some } \\
\text { systems, such as Kanban, } \\
\text { BK-CONWIP and B- } \\
\text { CONWIP. It is essential to } \\
\text { compare them in order to } \\
\text { understand their performance } \\
\text { differences in some key } \\
\text { indicators, such as stock } \\
\text { levels and throughput rates. }\end{array}$ & $\begin{array}{l}\text { For a given environment: } \\
\text { Which PCS's (new or classical) is } \\
\text { better to control WIP? And } \\
\text { throughput? And a combination of } \\
\text { both metrics? }\end{array}$ \\
\hline \multicolumn{3}{|c|}{ PCS's in complex environments } \\
\hline Collaboration & $\begin{array}{l}\text { As production shop floors } \\
\text { become more complex, it is } \\
\text { necessary to understand how } \\
\text { PCS's can be combined in } \\
\text { order managers could choose } \\
\text { solutions more adherent to } \\
\text { their environment. }\end{array}$ & $\begin{array}{l}\text { How new and old systems can be } \\
\text { combined horizontally (different } \\
\text { production stages) and vertically } \\
\text { (in different levels of the } \\
\text { hierarchical production planning)? }\end{array}$ \\
\hline $\begin{array}{l}\text { PCS in Supply } \\
\text { Chain }\end{array}$ & $\begin{array}{l}\text { As competitions against } \\
\text { supply chains, instead of } \\
\text { single organizations, are } \\
\text { becoming more usual, it is } \\
\text { important to studied PCS's is } \\
\text { this wider environment. }\end{array}$ & $\begin{array}{l}\text { How can a PCS be applied to whole } \\
\text { supply chains? } \\
\text { How companies shared information } \\
\text { among themselves to take shop } \\
\text { floor decisions? }\end{array}$ \\
\hline
\end{tabular}




\begin{tabular}{|c|c|c|}
\hline \multicolumn{3}{|c|}{ Environmental forces } \\
\hline $\begin{array}{l}\text { Technology } \\
\text { and Industry } \\
4.0\end{array}$ & $\begin{array}{l}\text { Technology development can } \\
\text { affect greatly actual PCS's as } \\
\text { well as the proposal of new } \\
\text { ones. For example, big data } \\
\text { and analytics can become } \\
\text { extremely complex } \\
\text { centralized PCS's, while } \\
\text { internet of machines can push } \\
\text { new systems to a } \\
\text { decentralized direction. }\end{array}$ & $\begin{array}{l}\text { How the use of technologies, } \\
\text { especially the ones emerging with } \\
\text { Industry } 4.0 \text {, can affect the } \\
\text { development and choice of PCS's? } \\
\text { How can artificial intelligence, } \\
\text { internet of things and machine } \\
\text { learning become feasible } \\
\text { decentralized systems on which } \\
\text { each machine could take decisions } \\
\text { based on the past experiences and } \\
\text { communicate one with the other? }\end{array}$ \\
\hline Sustainability & $\begin{array}{l}\text { Questions such as carbon } \\
\text { emission, reduction of waste } \\
\text { and energy economy, among } \\
\text { others, can lead to different } \\
\text { objectives of PCS's in the } \\
\text { next years, because } \\
\text { traditional ones do not focus } \\
\text { on these questions. For } \\
\text { example, a PCS focus on } \\
\text { reducing carbon emission } \\
\text { may neither control } \\
\text { throughput rates nor WIP, but } \\
\text { a third metric. This could lead } \\
\text { to a new group of PCS, } \\
\text { focusing on optimizing } \\
\text { sustainability objectives. }\end{array}$ & $\begin{array}{c}\text { How efficient is each PCS to deal } \\
\text { with carbon emission metric? And } \\
\text { with energy economy? } \\
\text { How can a new PCS be developed } \\
\text { seeking to optimize carbon } \\
\text { emission? } \\
\text { How can }\end{array}$ \\
\hline $\begin{array}{l}\text { Circular } \\
\text { Economy }\end{array}$ & $\begin{array}{l}\text { The objective to maximize } \\
\text { the circularities of products } \\
\text { can also affect the choice and } \\
\text { development of new PCS. }\end{array}$ & $\begin{array}{l}\text { How can real time communication } \\
\text { between market conditions and the } \\
\text { machine themselves predict better } \\
\text { deliver times to clients, optimize } \\
\text { set ups, increase efficiency, reduce } \\
\text { stocks and revise expected lead } \\
\text { times based on the shop-floor } \\
\text { scenario? } \\
\text { How PCS's will deal with } \\
\text { remanufacturing, as it increases the } \\
\text { number of materials entry points on } \\
\text { shop floor as well as production } \\
\text { routings? }\end{array}$ \\
\hline \multicolumn{3}{|c|}{ Proposal of new PCS's } \\
\hline $\begin{array}{c}\text { Characteristics } \\
\text { of new PCS }\end{array}$ & $\begin{array}{l}\text { As identified the } \\
\text { characteristics of PCS's } \\
\text { developed over the last } 20 \\
\text { years, it is interesting to } \\
\text { evaluate how actual forces } \\
\text { will influence the proposal of } \\
\text { new PCS's in the next years. }\end{array}$ & $\begin{array}{l}\text { What will be the characteristics of } \\
\text { PCS's in the next } 10 \text { or } 20 \text { years? } \\
\text { Will they still be based on Lean or } \\
\text { another approach will become } \\
\text { predominant? } \\
\text { How systems will deal with the } \\
\text { increasing complexity on } \\
\text { production environments? }\end{array}$ \\
\hline
\end{tabular}


Figure 1. Systematic Literature Review.

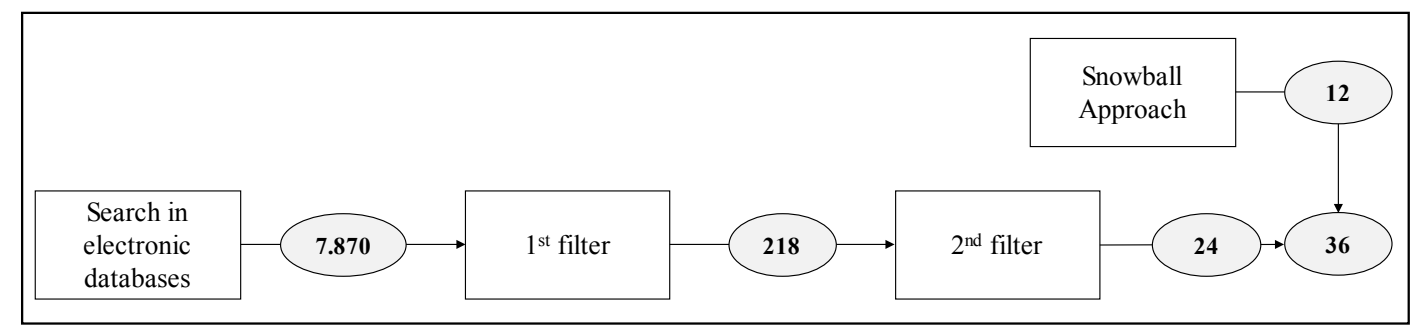

Figure 2. Base Stock and Inverse Base Stock.

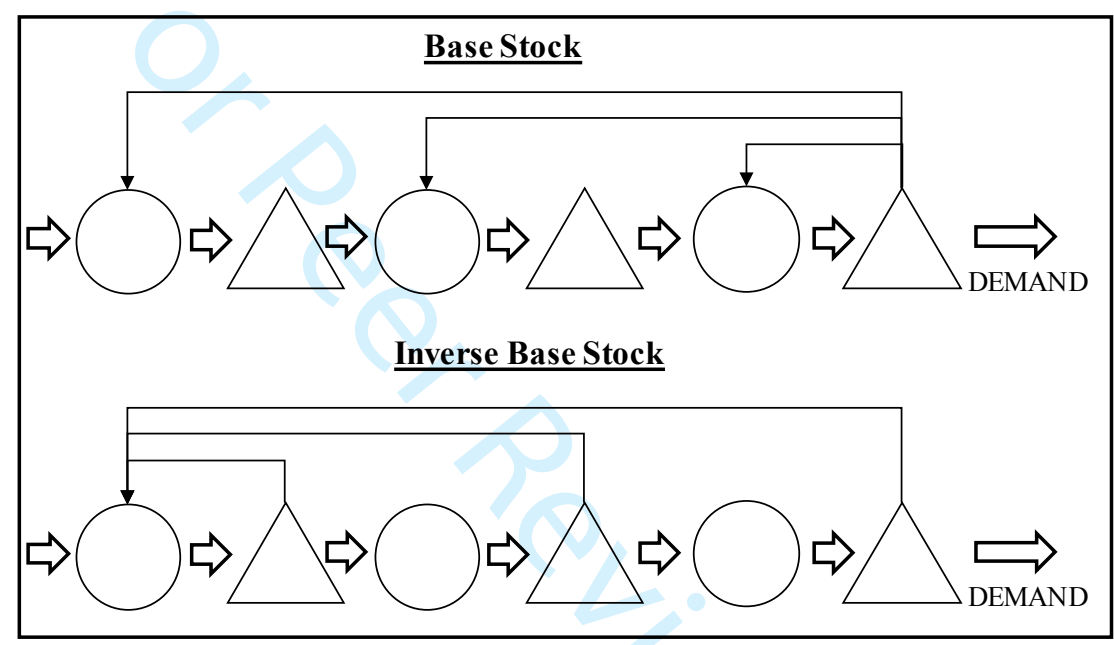

Source: Adapted from Masin, Herer, and Dar-El (1999) and Masin, Herer, and Dar-El (2005).

Figure 3. Customised token-based systems.

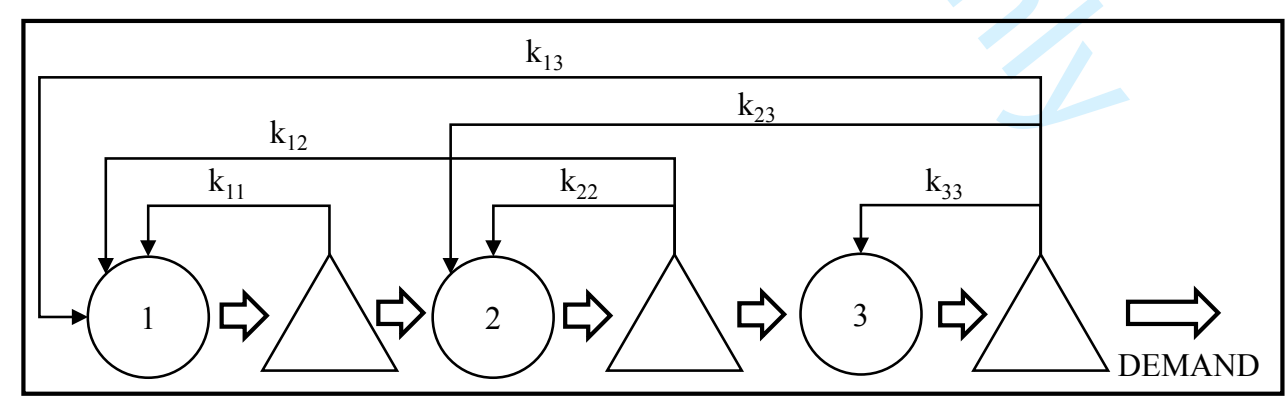

Source: Adapted from González-R et al. (2007). 
Figure 4. Behaviour-Based Control authorizations.

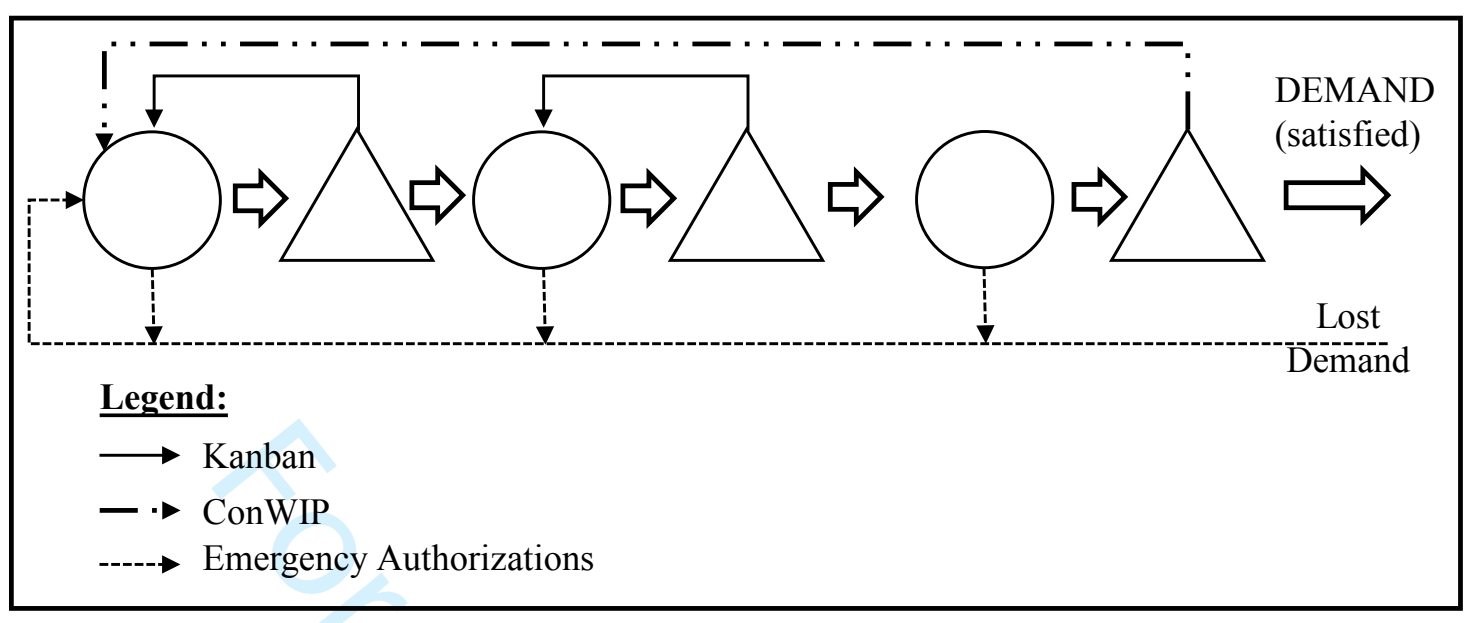

Source: Adapted from Paternina-Arboleda and Das (2001).

Figure 5. Gated MaxWIP.

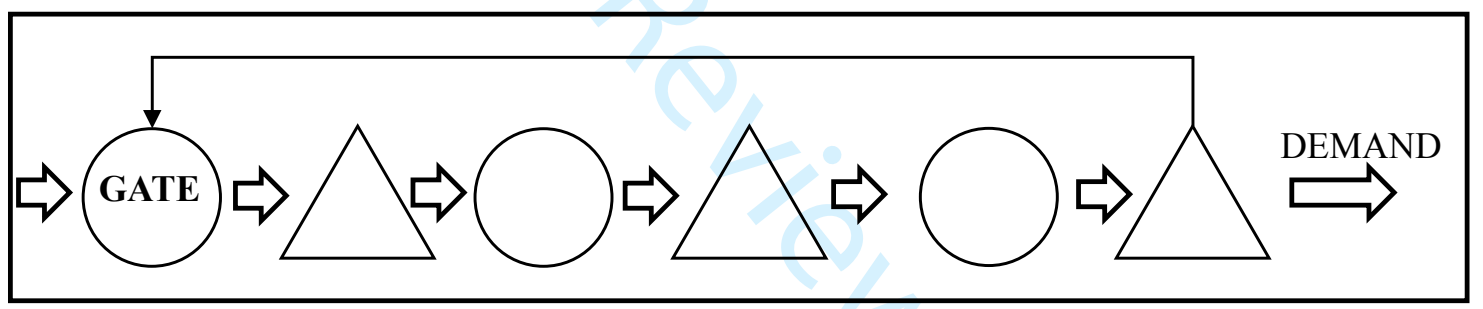


Figure 6. Parallel Pull Flow.

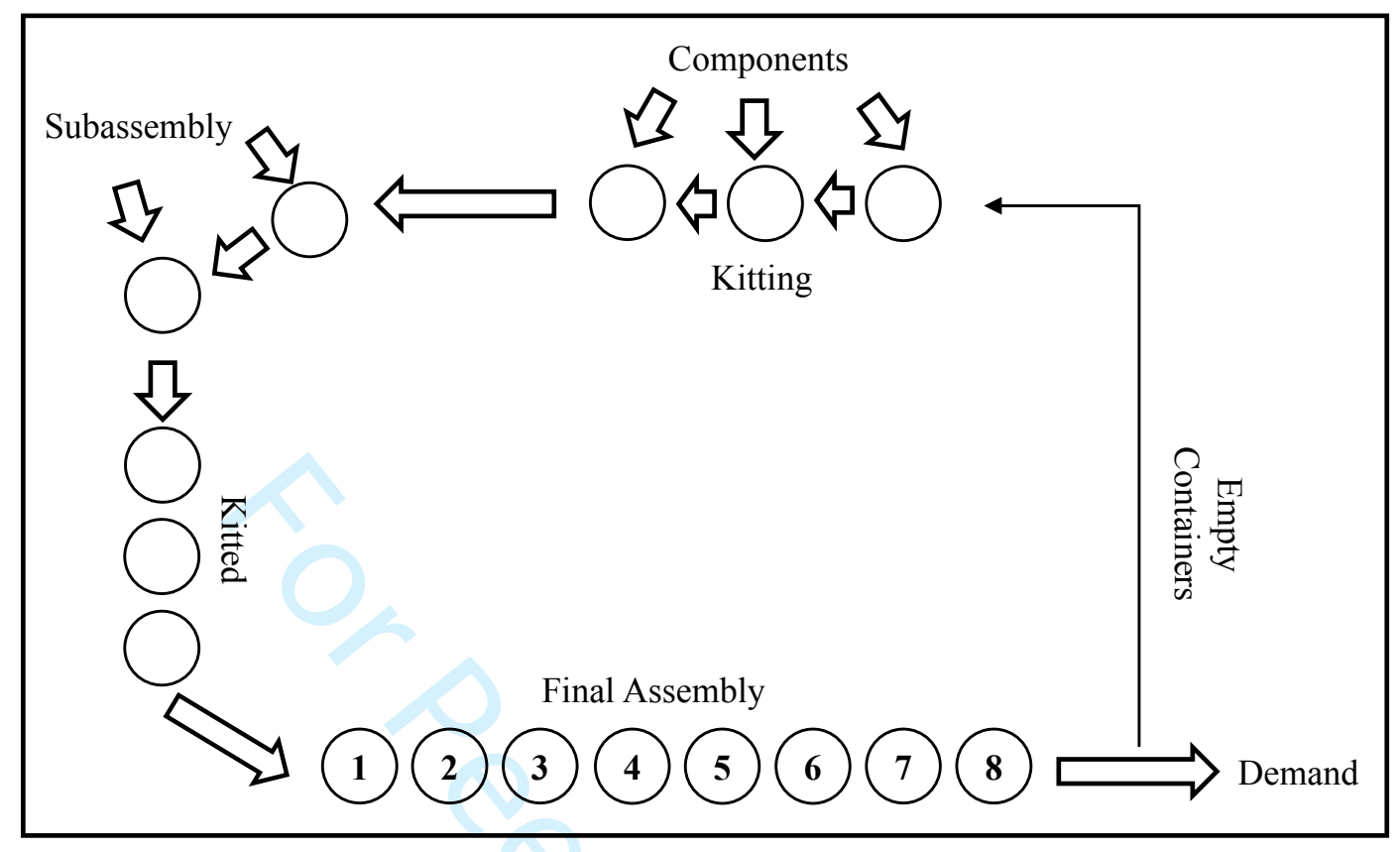

Source: Adapted from Hunter (2004).

Figure 7. COBACABANA card loop.

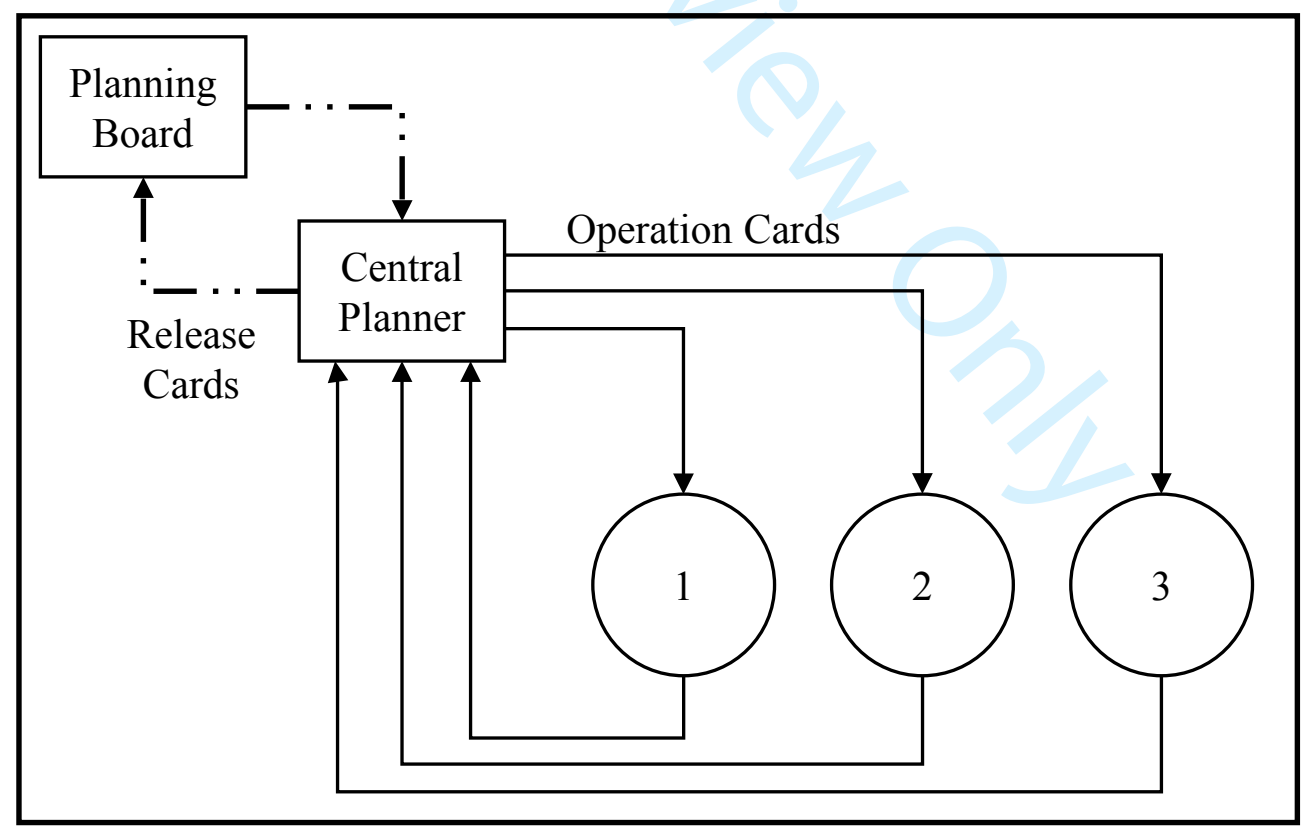

Source: Adapted from Thürer, Land, and Stevenson (2014). 
Figure 8. COBACABANA planning board.

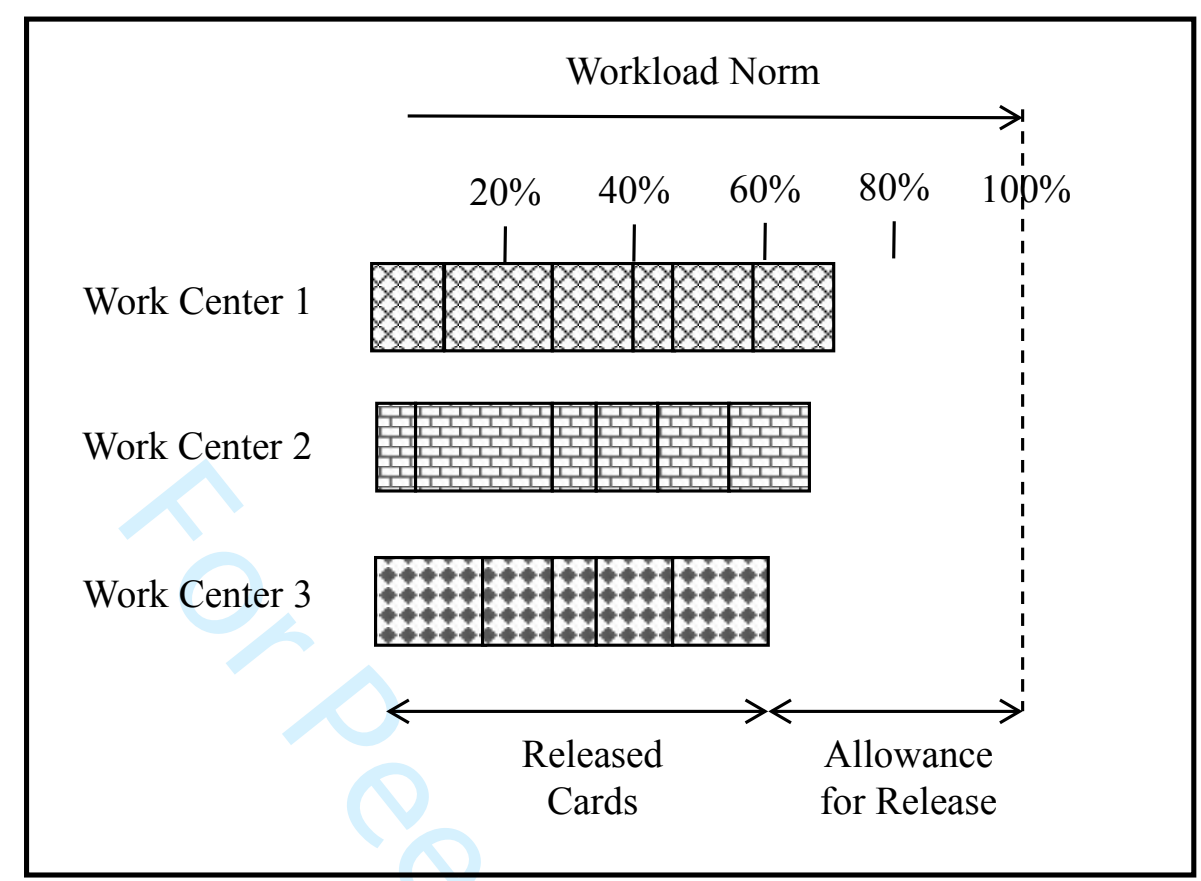

Source: Adapted from Thürer, Land, and Stevenson (2014).

Figure 9. BK-CONWIP.

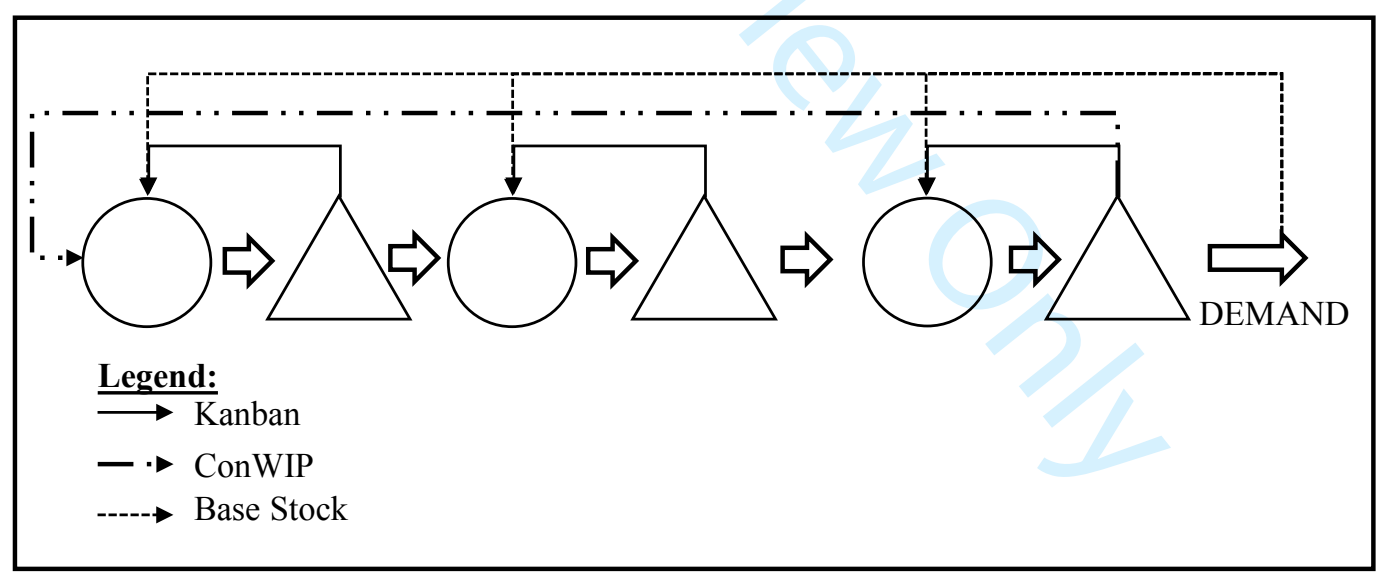


Figure 10. B-CONWIP.

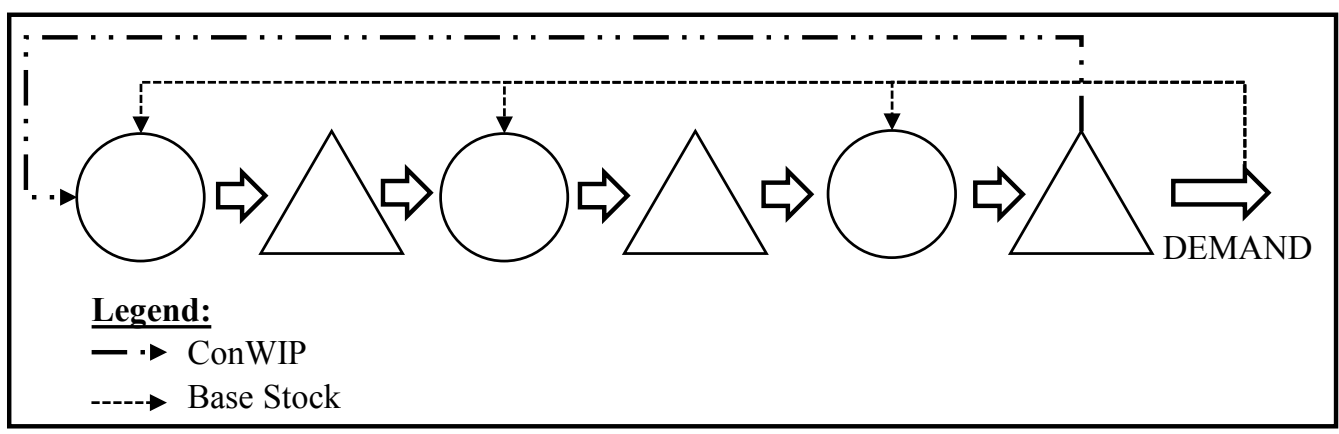

Figure 11. DSSPL.

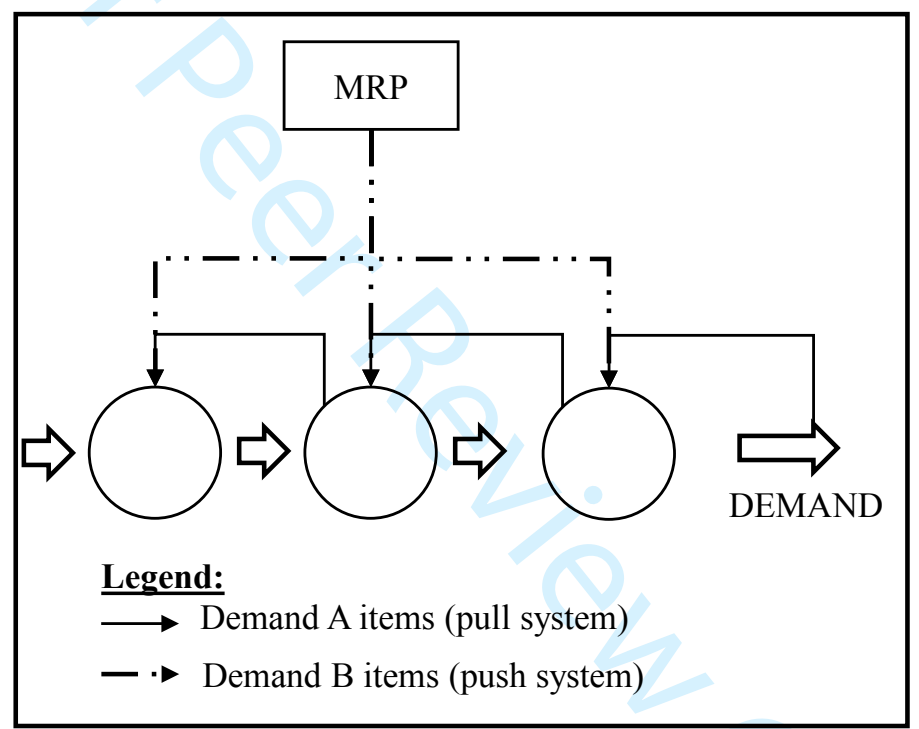

Source: Adapted from Cheikhrouhou (2007) 
Figure 12. DDMRP.

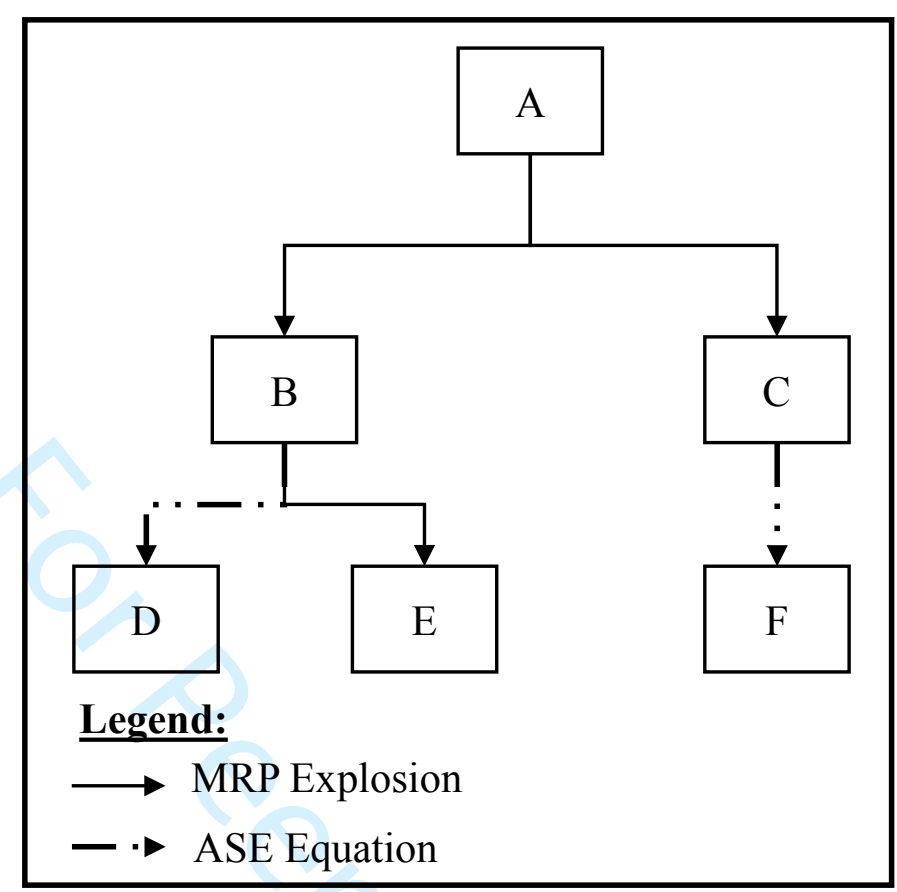

Figure 13. REDUTEX.

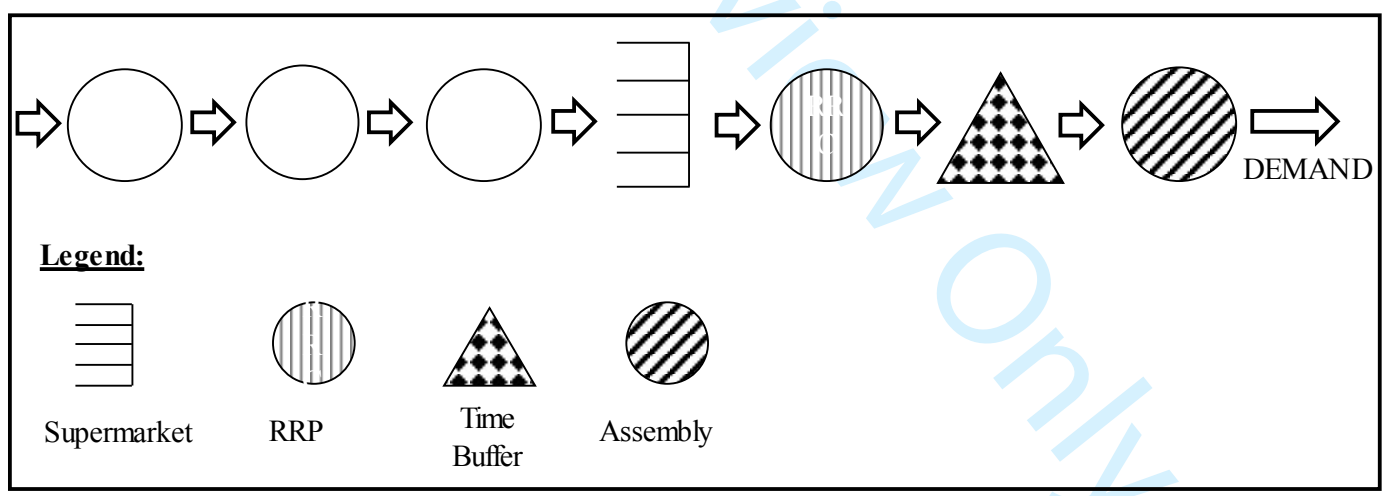


Figure 14. CONLOAD.

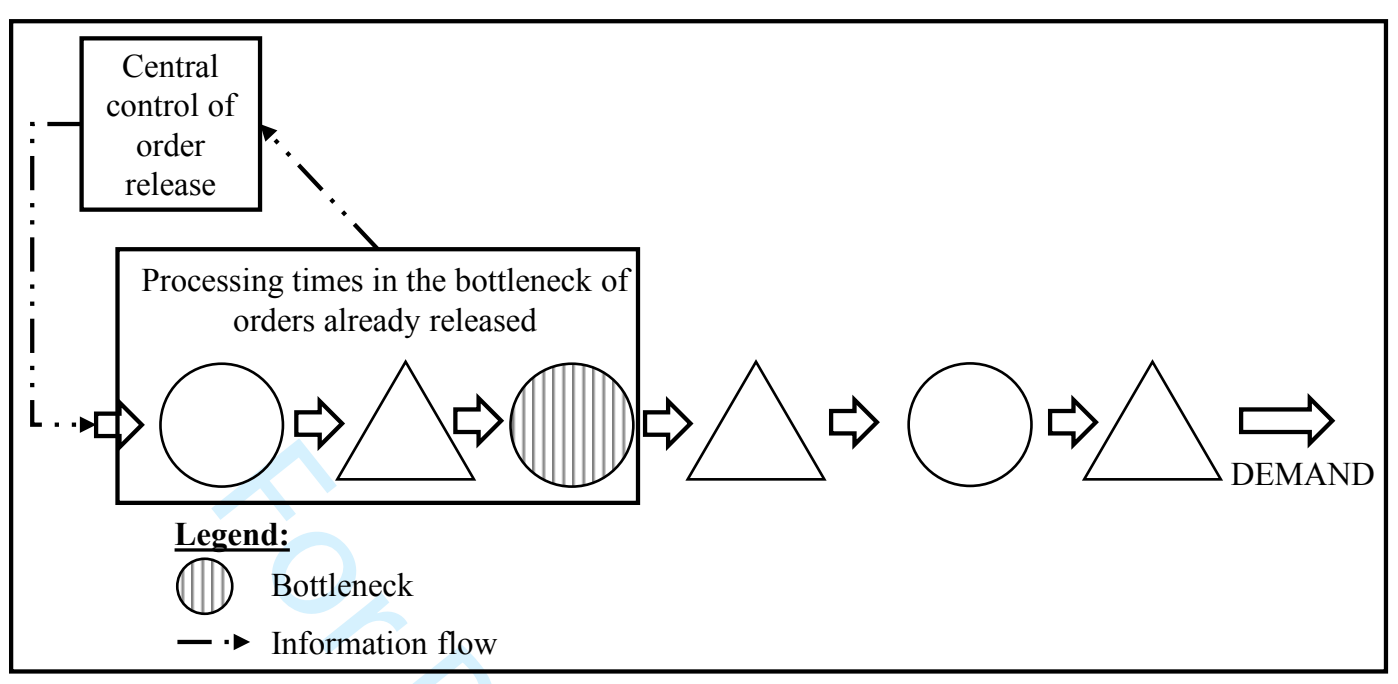

Figure 15. DEWIP.

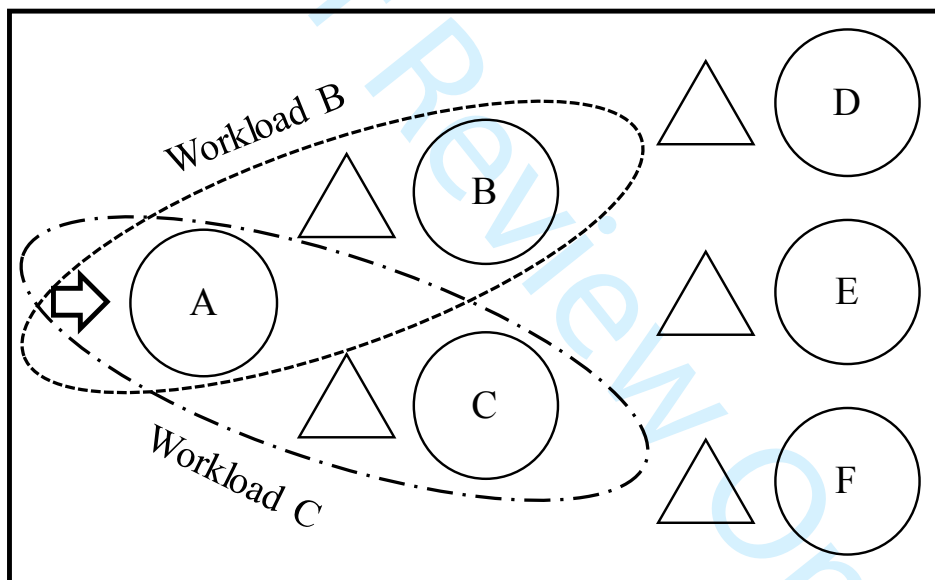

Legend:

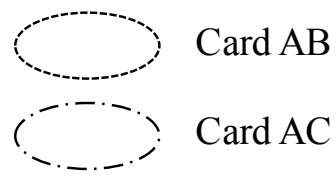


Figure 16. Production Control Systems evolution from 1999 to 2018.

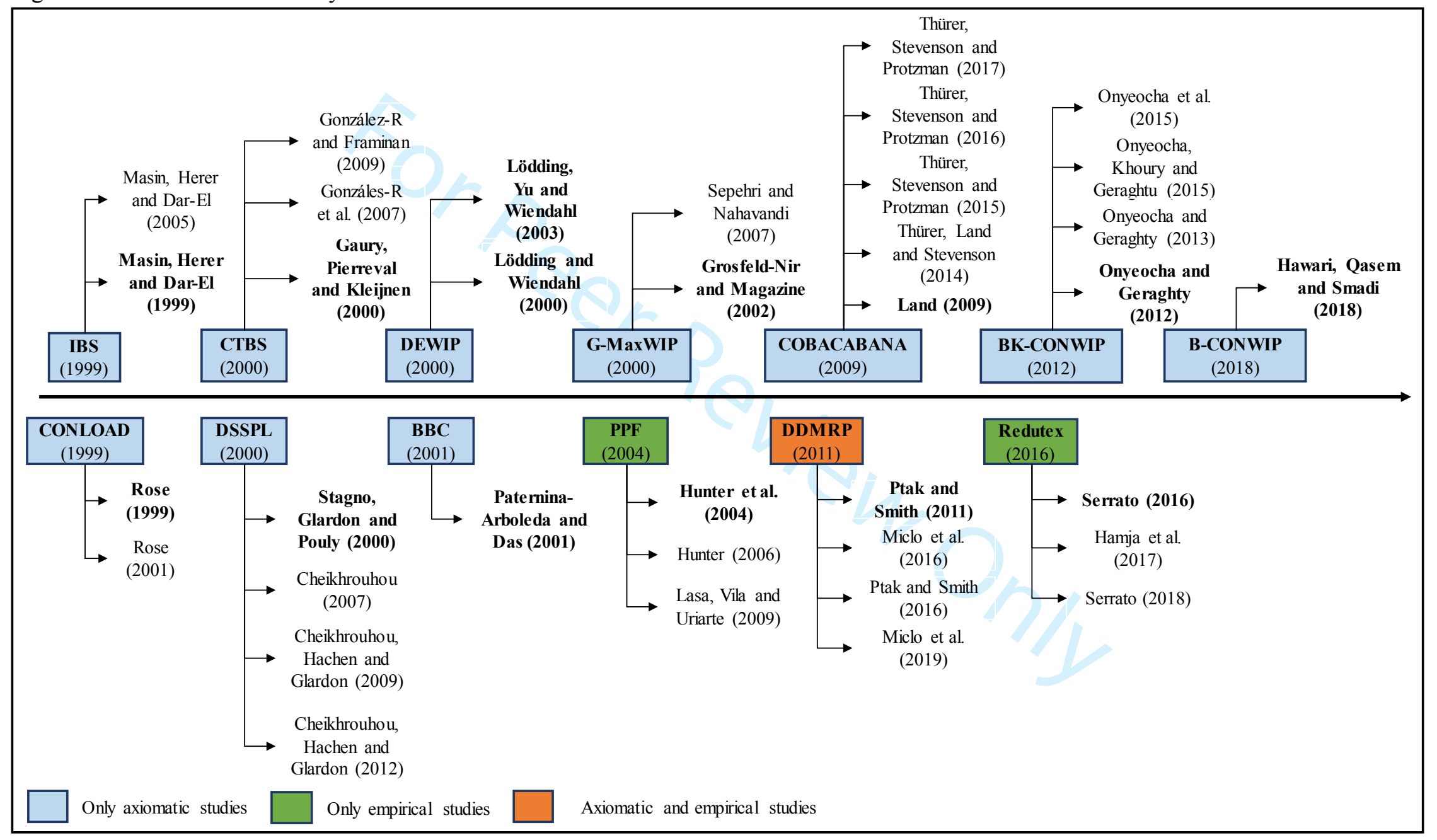


